\title{
Selectivity Guidelines and a Reductive Elimination-Based Model for Predicting the Stereochemical Course of Conjugate Addition Reactions of Organocuprates to $y$-Alkoxy- $\alpha, \beta$-Enoates
}

\author{
Artem S. Kireev, Madhuri Manpadi, and Alexander Kornienko \\ Department of Chemistry, New Mexico Institute of Mining and Technology, Socorro, New Mexico \\ 87801
}

\begin{abstract}
Current models used to predict the stereochemical outcome of organocopper conjugate addition processes focus on the nucleophilic addition step as stereochemistry-determining. Recent kinetic, NMR, kinetic isotope effect and theoretical density functional studies strongly support the proposal that stereochemical preferences in these processes are dictated by the reductive elimination step, transforming $\mathrm{Cu}^{\mathrm{III}}$ to $\mathrm{Cu}^{\mathrm{I}}$ intermediates. A new model that considers various steric and stereoelectronic factors involved in the transition state of the reductive elimination step is proposed and then used to interpret the results of systematic studies of arylcuprate conjugate addition reactions with cis and trans $\gamma$-alkoxy- $\alpha, \beta$-enoates. The results give rise to the following selectivity guidelines for this process. To achieve high anti-addition diastereoselectivities the use of trans esters with a bulky non-alkoxy substituent at the $\gamma$-position is recommended. While stereoelectronics disfavor syn-addition, a judicious choice of properly sized $\gamma$-substituents may lead to the predominant formation of syn-products, especially with cis enoates. However, high syn-selelectivities may be achieved by using $\gamma$-amino- $\alpha, \beta$-enoates.
\end{abstract}

\section{Introduction}

Conjugate addition reactions of organocopper reagents to $\alpha, \beta$-unsaturated carbonyl compounds represent important methods for carbon-carbon bond construction. ${ }^{1}$ Control of stereoselectivity in these reactions has attracted considerable attention from both theoretical and synthetic viewpoints. ${ }^{2}$ Diastereoselective addition processes with cyclic enones and enoates are highly predictable and have proven to be particularly useful. In contrast, stereochemical outcomes of reactions of conformationally flexible acyclic substrates are much less predictable and these processes often produce mixtures of epimeric products. To make matters worse, the acyclic diastereomers generated in these reactions are rarely well-resolved chromatographically.

Despite being plagued by these problems, reactions of $\alpha, \beta$-enoates containing $\gamma$-stereocenters have found significant utility in synthesis. Most prominent in this respect are reactions of organocuprates with trans $\gamma$-alkoxy- $\alpha, \beta$-enoates, which commonly yield products possessing an anti-stereochemical relationship between the $\gamma$ - and the newly formed $\beta$-stereocenters. Although the magnitude of anti-selectivity varies from moderate to high, it is consistently observed in reactions of alkyl, alkenyl and arylcuprates. 3,4 The uniformity of this stereochemical outcome has prompted various investigators to propose transition state models that can be used to predict the stereoselectivity of new transformations. 
The most direct interpretation of anti-selectivity employs the "modified Felkin-Anh" model, in which the carbonyl group in the aldehyde of the original model (Figure 1a, A) ${ }^{5}$ is replaced by the enoate $\mathrm{C}-\mathrm{C} \pi$-bond (Figure $1 \mathrm{~b}$ ). ${ }^{6}$ Originally discussed by Roush more than 20 years ago, ${ }^{6},{ }^{b}$ this model suggests that nucleophilic attack by an organocuprate takes place from the face opposite to a $\gamma$-alkoxy substituent via the preferred reactive conformation $\mathbf{B}$ rather than C owing to allylic 1,3-strain that is present in $\mathbf{C}$. Yamamoto and coworkers have systematically studied the dependence of the stereoselectivity on organocopper reagent type and enoate double bond geometry. This effort led to the discovery of a diastereoselectivity reversal from anti to syn as the enoate geometry is changed from trans to cis. ${ }^{7 a, b}$ A stereochemical model, involving a transition state in which an $\mathrm{R}$ group is oriented anti to the approaching nucleophile and an alkoxy group is located at an "inside" position (Figure 1c, D), was proposed. These investigators argued that this conformation is stabilized by mixing of the $\sigma$-orbital of an electron-rich C-R bond with the developing $\sigma^{*}$-orbital of an electron deficient incipient $\mathrm{Nu}-\mathrm{C}$ bond, a proposal analogous to one serving as the basis for the Cieplak electronic model. ${ }^{8}$ While experimental ${ }^{9}$ and theoretical ${ }^{10}$ support for the "inside" OR' preference in ground state enoates exist, the structure of the reactive conformer in the conjugate addition process is not necessarily similar to the ground state one. Despite having this weakness, this model explains the syn-selectivity observed in reactions with cis enoates, since allylic 1,3-strain would force an OR' group into an "outside" position as shown in the reactive conformer $\mathbf{E}$.

Importantly, a chelation model, which is often used successfully to predict the stereochemical outcome of organometallic addition reactions with $\gamma$-alkoxy carbonyl compounds, is of less significance due to the lower chelation ability of organocopper reagents relative to organolithium and organomagnesium counterparts. Yamamoto and coworkers have shown that diastereoselectivity trends in organocuprate additions of $\gamma$-OTBS and $\gamma$-OBn enoates are similar. Because TBSO group is considered non-chelating, this observation supports the view that chelation is negligible in these reactions. ${ }^{7 b}$

As part of a synthetic program aimed at developing practical pathways for the synthesis of medicinally promising Amaryllidaceae constituents (Figure 2), we have extensively utilized conjugate addition reactions of functionalized aromatic copper reagents with various $\gamma$-alkoxy$\alpha, \beta$-enoates. ${ }^{3 r}, 6 \mathrm{j}$ The relative cis orientation of an aromatic group and an adjacent oxygen (marked with asterisks below) is highly conserved in this series of natural products. This corresponds to an anti-stereochemical relationship of these groups in an open-chain precursor.

The practicality and scalability of the synthetic sequences employed in our efforts rely to a large extent on the requirement that the arylcuprate conjugate addition reactions take place with anti-diastereoselectivities exclusively. Although we have been successful with the empirical optimization of reaction conditions needed for the exclusive formation of antiproducts, we have also searched for a unified, theoretically based stereochemical model to guide these efforts. While both the modified Felkin-Anh and Yamamoto models have the virtue of simplicity, it now appears that they are fundamentally flawed in view of the recent experimental and theoretical mechanistic investigations of organocuprate conjugate addition process. ${ }^{11}$ Below, the details of a systematic investigation of arylcuprate reactions with $\gamma$ alkoxy- $\alpha, \beta$-enoates are given. In addition, a new stereochemical model, which is consistent with the results of both the current effort and that previously reported by other investigators as well as the current mechanistic understanding of this process, is proposed.

\section{Results}

In the pursuit of practical synthetic approaches to Amaryllidaceae constituents, we recently conducted a study of arylcuprate conjugate addition reactions of a series of $\gamma, \delta, \varepsilon-$ trialkoxyenoates, derived from various carbohydrate precursors (Figure 3). ${ }^{12}$ In each one of 
these processes, a single anti-addition product was formed regardless of the identity of the alkoxy groups (OBn or OMOM) or their relative stereochemical relationship. These observations imply that even in complex settings 1,2 -asymmetric induction by a $\gamma$-stereocenter is the predominant stereochemistry-determining factor in the transition states of the addition processes.

To elucidate the sufficiency of a single $\gamma$-alkoxy stereocenter to attain exclusive antiselectivities as well as other structural features that would be necessary for such a highly diastereoselective process, we synthesized enoates 1-7 (Figure 4) varying in the identity of the $\gamma$-alkoxy group OR' ( $\mathbf{1}$ vs 2 ), the steric bulk of the group R ( 2 vs $\mathbf{3}$ vs $\mathbf{4}$ and $\mathbf{5}$ vs $\mathbf{6}$ vs $\mathbf{7}$ ) and the double bond geometry ( 2 vs 5,3 vs 6,4 vs 7 ). While the synthesis of enoates 4 and 7 followed previously reported procedures starting from lactaldehyde, ${ }^{13}$ compounds $\mathbf{1}, \mathbf{2}, \mathbf{3}, \mathbf{5}$, $\mathbf{6}$ were prepared through sequences utilizing various known intermediates derived from Dmannitol. ${ }^{14}$ Underlying these approaches is the known $(E, Z)$-selectivity dependence on the solvent $\left(\mathrm{CH}_{2} \mathrm{Cl}_{2}\right.$ vs $\left.\mathrm{MeOH}\right)$ in reactions of $\alpha$-alkoxyaldehydes with stabilized Wittig reagents. 15

We further investigated the reactions of 1-7 with a series of arylcuprates, derived from various multi-substituted aromatic Grignard reagents (a-f, Table). With enoates $\mathbf{1}$ and $\mathbf{2}$ as substrates, only single (by ${ }^{1} \mathrm{H}$ NMR analysis of crude and purified product mixtures) diastereomeric addition products were formed in all reactions. Chemical correlation of the phenyl adducts 12a and 13a with the known lactones 19 and $20^{16}$ confirmed the anti-stereochemical outcome of the cuprate reactions (Figure 5). The results strongly argue in favor of the adequacy of a single $\gamma$-alkoxy stereocenter for governing exclusive (within the NMR detection limit) antiselectivities and bode well for future synthetic applications of this methodology, especially in cases where scale-up is anticipated. Combined with the similar results obtained in experiments with $\gamma, \delta, \varepsilon$-trialkoxyenoates these findings lead to the tempting speculation that the chemical nature of the $\mathrm{R}$ group (but not its size) has little influence on reaction stereoselectivity.

Further, reactions of the trans enoates showed a progressive erosion of anti-selectivity as the size of the $\mathrm{R}$ decreased $(\mathbf{2} \rightarrow \mathbf{3} \rightarrow \mathbf{4})$. In contrast, the reactions of the cis enoates, while being moderately anti-selective (enoates $\mathbf{6}$ and $\mathbf{7}$ ), did not display consistent selectivity dependence on the $\mathrm{R}$ group. The chemical correlation of the epimeric phenyl adduct mixtures 14a and 15a with the known trans and cis pairs of lactones $19,20^{16}$ and $\mathbf{2 1}, \mathbf{2 2}^{17}$ led to the assignment of stereochemistry for the major and minor diastereomers (Figure 6).

\section{Discussion}

In principle, the observations made in studies with trans enoates can be adequately interpreted on the basis of the modified Felkin-Anh model (Figure 1b). According to this model, the stereochemistry of the addition process should not depend on the identity of the alkoxy substituent which is oriented anti to the incoming nucleophile. In agreement with this prediction, no difference was seen between reactions of the $\gamma$-OMOM and $\gamma$-OBn enoates 1 and 2. Moreover, others have reported high anti-addition selectivities in reactions with $\gamma-\mathrm{OMe}$, $6 \mathrm{a}, \mathrm{b}, \mathrm{f} \gamma-\mathrm{OBOM}, 3 \mathrm{j}, \mathrm{m}, \mathrm{n}, \mathrm{q}, \mathrm{s} \gamma-\mathrm{O}-\mathrm{CR}_{2}-\delta-\mathrm{O}$, (part of a ketal with a vicinal oxygen), $3 \mathrm{a}, \mathrm{b}, \mathrm{k}, \mathrm{p}, 6 \mathrm{~g}$ $\gamma$-OMTM ${ }^{6 \mathrm{f}}$ and $\gamma$-OMPM ${ }^{3 \mathrm{f}}$ enoates. The Felkin-Anh model also suggests that large $\gamma$-R groups further destabilize the transition state conformer $\mathbf{C}$ leading to syn-products. The results of experiments with enoates $\mathbf{2 , 3}$ and $\mathbf{4}$ match this expectation. Interestingly, application of the Yamamoto model for organocuprate conjugate additions leads to an opposite prediction; specifically that the stereochemical outcome of these processes should be strongly dependent on the identity of the alkoxy group and that a change in the size of the anti oriented $\mathrm{R}$ group should result in only a small perturbation. 
Importantly, the low stereochemical selectivities observed for conjugate addition reactions of cis enoates cannot be explained by using either of these models or even by invoking a more complex four-conformer equilibrium process which mixes both models. For example, the modified Felkin-Anh interpretation predicts improved anti-selectivities, since 1,3-strain, the main factor causing energetic difference between conformers $\mathbf{B}$ and $\mathbf{C}$, significantly increases in transition states for reactions of the cis enoates. In contrast, a preponderance of syn-products would be expected on the basis of the Yamamoto model due to allylic strain-promoted destabilization of the conformer $\mathbf{D}$.

It is clear that synthetic applications of organocuprate conjugate additions to enoates have outpaced the mechanistic understanding of these reactions. As a result, the recent, insightful experimental and theoretical investigations of the mechanism of organocopper reactions ${ }^{11}$ had not been included in developing models for predicting the stereochemical course of these processes. The fundamental assumption made in developing the modified Felkin-Ahn and Yamamoto models is that diastereofacial selection takes place during the first step involving either copper-olefin $\pi$-complex formation or simple nucleophilic addition of the cuprate. $6 \mathrm{f}$,

$7 \mathrm{~b}$ Yet, detailed studies by several research groups ${ }^{18}$ clearly indicate that the carbon-carbon bond forming reductive elimination step, converting $\mathrm{Cu}^{\mathrm{III}}$ to $\mathrm{Cu}^{\mathrm{I}}$ intermediates, is both rateand stereochemistry-determining. Recent theoretical studies by Nakamura and coworkers 19 have provided a more detailed mechanistic description that has been adapted in developing a new model (Figure 7) for predicting the stereochemical course of organocuprate $\gamma$-alkoxy$\alpha, \beta$-enoate conjugate addition reactions.

In the route for organocuprate conjugate additions, $\pi$-complexation of a cuprate reagent with the enoate double bond is followed by reversible formation of the $\beta$-cuprio(III) enolate, in which the high oxidation state of copper is stabilized by the donation from the electron-rich enolate double bond. A correlation of the results of density functional studies with those arising from experimental ${ }^{13} \mathrm{C}$ NMR ${ }^{19 b}$ and kinetic isotope effect investigations, ${ }^{18 i}$ demonstrates that $\beta$-cuprio(III) enolates are direct precursors of addition products with enals and enones, formed through rate- and stereochemistry-determining reductive elimination. ${ }^{20}$ With less reactive esters a Lewis acidic or electrophilic additive, such as $\mathrm{BF}_{3}$ or $\mathrm{Me}_{3} \mathrm{SiCl}$, is required to reduce the electron-rich enolate double bond character, thus destabilizing the $\mathrm{Cu}^{\mathrm{III}}$ intermediate and promoting reductive elimination to generate $\mathrm{Cu}^{\mathrm{I}}$ species. Clearly, a model aimed at understanding and predicting the stereochemical course of organocopper conjugate addition processes should center on the reductive elimination step in this general pathway. Both the modified Felkin-Anh and Yamamoto models are inconsistent with this new mechanistic information. Furthermore, processes involving these models in the first mechanistic step evolve into highly energetic reductive elimination transition state conformations that are highly destabilized by eclipsing interactions (Figure $8, \mathbf{F}$ and $\mathbf{G}$ ).

We propose a mechanistically more relevant approach to evaluating the stereochemistry of organocuprate enoate conjugate additions. The "Reductive Elimination" model focuses on competitive transition states $(\mathbf{H}$ and $\mathbf{I})$ for the $\mathbf{C}-\mathbf{C}$ bond formation step. In these transition states, the $\gamma-\mathrm{H}$ atom is oriented toward the cuprate cluster, thus minimizing steric strain associated with interactions of the large R and OR' substituents with the nearly planar copper complex. Reactive conformation $\mathbf{H}$, leading to the anti-product, is energetically more favorable than I from both stereoelectronic and steric perspectives. In the reductive elimination transition state the $\mathrm{C}_{\beta}$ - $\mathrm{Ar}$ bond is forming, while $\mathrm{C}_{\beta}$-Cu bond is being broken. Both of these processes are facilitated in conformer $\mathbf{H}$ by the relative positioning of $\mathrm{R}$ and OR' which allows favorable mixing of the $\sigma$-orbital of the forming $\mathrm{C}_{\beta}$-Ar bond with the low lying $\sigma^{*}$-orbital of the $\mathrm{C}_{\gamma}$-OR' bond. In addition, donation from the electron-rich $\mathrm{C}_{\gamma}$-R bond into the $\sigma^{*} \mathrm{C}_{\beta}$-Cu orbital weakens the $\mathrm{C}_{\beta}$ - $\mathrm{Cu}$ bond and assists departure of copper. Importantly, both of these interactions increase during the course of reductive elimination due to the increasingly better overlap of the 
component orbitals; the dihedral angles $\mathrm{Ar}-\mathrm{C}_{\beta}-\mathrm{C}_{\gamma}-\mathrm{H}$ and $\mathrm{Cu}-\mathrm{C}_{\beta}-\mathrm{C}_{\gamma}-\mathrm{H}$ become larger as $\mathrm{Ar}-\mathrm{Cu}$ bond elongates. Furthermore, as the size of the group $\mathrm{R}$ increases, conformer $\mathrm{I}$ becomes increasingly disfavored due to allylic 1,3-strain. The results of the current study (Table) fully comply with this new stereochemical model.

Similar transition state models have been proposed by other investigators for reactions involving "flat" or "aerofoil" nucleophiles. ${ }^{21}$ An instructive example comes from a study by Reetz and coworkers of the stereochemistry of the cycloaddition reactions of ester $\mathbf{2 3}$ with diazomethane (Figure 9a). ${ }^{21 \mathrm{c}}$ The authors noted that the "flat" nature of the approaching $\pi$ system results in a consensus transition state conformation, in which the hydrogen atom points toward the incoming reagent and the bulky $\mathrm{NBn}_{2}$ group occupies an "outside" position, leading to the major cycloaddition product $\mathbf{2 4}$. As the size of the $\mathrm{R}$ group increased the ratio of the diastereomeric products 24:25 decreases, a consequence presumably of allylic 1,3-strain in the transition state to $\mathbf{2 4}$. Barrett and coworkers reported an interesting divergent stereochemical outcome in Michael addition reactions of nucleophiles to nitroolefin 26 (Figure 9b). "Small" nucleophiles (NaOMe, $\mathrm{NaOBn}$, TsNHK) led to highly selective formation of S-configured products $\mathbf{2 7}$, while reactions with "aerofoil" shaped nucleophiles, such as phthalimide K or succinamide K, give mainly R-adducts $28{ }^{21 \text { a }}$ Barrett noted that the modified Felkin-Anh transition state, leading to the $\mathrm{S}$-configured phthalimide adduct, suffers from a steric interaction between the phthalimide carbonyl and the C-3 oxygen substituent. This steric congestion would be minimized in the transition state leading to $\mathbf{2 8}$ even though it is not favored stereoelectronically.

The "Reductive Elimination" model accounts for the significant decrease in anti-selectivity observed in conjugate addition reactions of cis enoates 5-7. The severe 1,3-strain that arises when cis double bond geometry is present leads to rotation about the $\mathrm{C}_{\beta}-\mathrm{C}_{\gamma}$ to produce an energetic minimum (Figure 10). Reactive conformations $\mathbf{J}$ and $\mathbf{K}$ may become more competitive and, conceivably, the absence of a clearly defined transition state preference leads to small selectivity values. Although Yamamoto and coworkers reported selectivity reversal from anti to syn when the enoate geometry is changed from trans to cis, their results show that anti-selectivities in reactions with trans enoates are high, while syn-stereochemical preference with cis enoates was at best marginal (on the order of $2: 1$ to $3: 1$ ). ${ }^{7 a, b}$

The "Reductive Elimination" model can also be used to understand the significant decrease in reaction yields and an increase in reaction times from $6 \mathrm{~h}$ at $-30{ }^{\circ} \mathrm{C}$ for trans enoates 1-4 to 24-48 $\mathrm{h}$ at $25^{\circ} \mathrm{C}$ for cis enoates 5-7 found in this study. Other investigators have reported similar observations, including the complete failure of cis enoates to undergo conjugate additions compared to facile reactions of their trans counterparts. $2 \mathrm{~b}, 7 \mathrm{a}, \mathrm{b}$ In this connection it is noteworthy that several research groups have reported that identical stereoselectivitites accompany reactions of trans and cis enoates. $2 \mathrm{~b}, 3 \mathrm{f}, \mathrm{t}, \mathrm{6a}, \mathrm{b}, \mathrm{g}$ While cis $\rightarrow$ trans enoate isomerization in organocuprate reactions is a logical interpretation, an electron transfer mechanism for this process has been substantially refuted. ${ }^{11}$ The density functional investigation by Nakamura and coworkers suggests that the 3 -cuprio(III) enolate may be viewed as a copper (III) species with the enolate double bond serving as a ligand. ${ }^{19 \mathrm{a}} \mathrm{In}$ addition, the early experiments by Corey and Boaz indicate that this species may undergo silylation with $\mathrm{Me}_{3} \mathrm{SiCl}$ changing the stereochemical course of the addition process. ${ }^{20}$ This conclusion is further supported by the results of kinetic isotope studies (with ${ }^{17} \mathrm{O}$ replacement at the carbonyl oxygen) by Frantz and Singleton ${ }^{18 \mathrm{k}}$ which show that silylation with $\mathrm{Me}_{3} \mathrm{SiCl}$ could be rate-limiting. Thus, it is not inconceivable that the slow reactivity of cis enoates enables silylation of the 3-cuprio(III) enolate to take place, a process which weakens the donor ability of the enolate double bond (Figure 11). Ligand exchange (with HMPA or THF) may allow rotation about the $\mathrm{C}_{\alpha}-\mathrm{C}_{\beta}$ bond leading to a 3-cuprio(III) enolate that would be derived directly from the trans enoate starting material. It is not unlikely that the marginal excesses of 
anti-addition products formed in reactions of enoates 5-7 are a consequence of competing double bond isomerization of the reactants. It should be noted, that Yamamoto and coworkers performed their addition reactions in the presence of $\mathrm{BF}_{3}$ as an activating agent compared with $\mathrm{Me}_{3} \mathrm{SiCl}$ used in our experiments.

The "Reductive Elimination" model can be effectively applied to predicting the stereochemistry of conjugate addition reactions of other types of $\gamma$-stereocenter-containing enoates. If an alkoxy substituent is not present at the $\gamma$-position, the stereochemical outcome will depend on the relative sizes of the two non-hydrogen substituents. For example, ethyl E-4-phenyl-2-pentenoate (Figure 12) is known to react with $\mathrm{Bu}_{2} \mathrm{CuLi} \cdot \mathrm{BF}_{3}$ to yield mainly the anti-product (anti:syn $=7: 3$ ). ${ }^{7 \mathrm{~g}}$ When the $Z$-enoate is reacted with the copper reagent, stereochemistry reversal (anti:syn $=3: 7$ ) is observed. It is possible that in the $Z$-enoate case the 1,3-strain is minimized in a transition state conformation in which the smaller Me group is close to the copper complex (bottom transition state in Figure 12). This would result in preferential formation of the syn-product. Thus, in reactions of trans enoates that lack $\gamma$ substituents capable of exerting strong stereoelectronic effects, a transition state conformation that places the smaller of the two non-hydrogen groups into the 1,3-strain position would lead to an accurate prediction of the stereochemical outcome. Similar selelectivity patterns have also been reported by Yamada and his coworkers in their systematic studies with enoates and enones containing a methyl group and a large steroidal substituent at the $\gamma$-position. ${ }^{2 b}$

Reactions of trans $\gamma$-amino- $\alpha, \beta$-enoates with organocopper reagents generally take place with synstereoselectivities. ${ }^{22}$ While these processes have been extensively employed in synthesis, no logical reason for why their stereochemistry is opposite to that observed with $\gamma$-akoxy- $\alpha, \beta$ enoates has been offered. Interestingly, application of the new model to reactions of the trans $\gamma$-amino- $\alpha, \beta$-enoate substrates nicely explains this stereochemical divergence. Accordingly, a lower energy reductive elimination transition state conformation which has the bulky amino group 23 in the "outside" position (Figure 13) would result in formation of the observed synproducts. ${ }^{22 \mathrm{a}}$ Importantly, when the other non-hydrogen subsituent is large, this transition state would be of exceptionally high energy and, as a result, the enoate would be unreactive towards conjugate addition. ${ }^{6 f}$ It is noteworthy, that the application of the Felkin-Anh model is equally successful with $\alpha$-amino-aldehydes as it is with $\alpha$-alkoxy-aldehydes. Yet, the modified FelkinAnh hypothesis predicts anti-selelectivity for $\gamma$-amino- $\alpha, \beta$-enoates, which is not what is observed experimentally.

A last point worth making stems from the proposal that if the transition state model works well for predicting two synthetically distinct organocopper-promoted processes then there is a high probability that the two processes follow similar mechanistic pathways. The case in point is the $S_{N} 2^{\prime}$ reaction of allylic substrates with organocopper reagents where little is known about the mechanism. Experimental studies by Bäckvall and coworkers ${ }^{24}$ and density functional investigation by Nakamura and coworkers ${ }^{25}$ suggest that these reactions proceed through the intermediacy of $\pi$-allylcopper(III) intermediates. Furthermore, the conclusion of theoretical study is that C-C bond formation occurs not from $\sigma$-allylcopper(III) species, as had been thought previously, but rather via enyl $[\sigma+\pi]$-type transition states that are mechanistically similar to those involved in the enoate conjugate addition process. Since the selectivities of reactions of $\gamma$-substituted allylic halides follow a pattern $26,6 \mathrm{i}$ that is similar to that for enoate conjugate additions, we believe that the reductive elimination step is rate- and stereochemistrydetermining for organocuprate $\mathrm{S}_{\mathrm{N}} 2^{\prime}$ reactions as well (Figure 14). Importantly, the application of the modified Felkin-Anh model to these processes leads to the expectation that synstereochemistry would predominate, a prediction which opposes the experimental observations. We believe that this stereochemical analogy provides an important clue about the mechanism of $\mathrm{S}_{\mathrm{N}} 2^{\prime}$ reactions of organocuprates with allylic substrates, which matches the conclusions drawn from theoretical studies. 25 


\section{Conclusions}

The reductive elimination-based stereochemical model described above explains the high antiselectivities observed in organocopper conjugate addition reactions with trans $\gamma$-alkoxy- $\alpha, \beta-$ enoates. Both steric and stereoelectronic factors favor the transition state conformer that leads to the anti-adduct. However, it is possible to direct preferential formation of syn-products by judiciously choosing properly sized $\gamma$-substituents, especially in cis enoate reactants. In this event, steric factors outweigh stereoelectronic control. Analysis of previous observations demonstrates that the proposed model is fully consistent with the stereochemical outcomes of conjugate additions of other $\gamma$-stereocenter-containing enoates, such as those containing $\gamma$ $\mathrm{C}, \mathrm{C}, \mathrm{H}$ and $\gamma-\mathrm{C}, \mathrm{H}, \mathrm{N}$ substituents. Significantly, the model can be used to design highly diastereoselective conjugate addition processes. For example, by using trans $\gamma$-alkoxy- $\alpha, \beta-$ enoates containing larger $\gamma$-R group high anti-selective transformation should take place. In contrast, trans $\gamma$-amino- $\alpha, \beta$-enoates with small $\gamma$-R groups should be employed if syn-selective processes are desired. Also, the proposed stereochemical/mechanistic analogy with organocopper-mediated $\mathrm{S}_{\mathrm{N}} 2^{\prime}$ processes is expected to facilitate mechanistic investigations of this important synthetic method. Further work is underway to study the proposed transition states computationally and to validate the results of the theoretical analysis by designing more narrowly targeted experimental systems.

\section{Experimental Section}

\section{A. Preparation of Enoates}

Ethyl (2E,4S)-5-(tert-butyldiphenylsilanyloxy)-4-hydroxy-2-pentenoate (9)Compound $\mathbf{8}^{14 \mathrm{a}}(4.8 \mathrm{~g}, 24 \mathrm{mmol})$ was stirred in a mixture of water and acetic acid $(100 \mathrm{~mL}$, 1:3) for $20 \mathrm{~h}$ at room temperature. The mixture was evaporated under reduced pressure and the traces of acetic acid were removed by co-evaporating with toluene $(5 \times 10 \mathrm{~mL})$. The oily residue was dissolved in DMF $(26 \mathrm{~mL})$ and cooled to $0{ }^{\circ} \mathrm{C}$. To the mixture were added DMAP $(0.3 \mathrm{~g}$, $2.4 \mathrm{mmol})$, imidazole (1.94 g, $24.8 \mathrm{mmol}$ ) and tert-butyl(chloro)diphenylsilane (7.8 g, 28.4 $\mathrm{mmol}$ ). The resulting mixture was stirred overnight at room temperature. The reaction mixture was quenched with water $(20 \mathrm{~mL})$. The aqueous phase was extracted with $\mathrm{CH}_{2} \mathrm{Cl}_{2}(3 \times 30 \mathrm{~mL})$. The combined organic layers were washed with brine, dried $\left(\mathrm{MgSO}_{4}\right)$ and evaporated under reduced pressure. The residual oil was presorbed on silica gel and purified by column chromatography (5\% - 20\% EtOAc/hexanes) to afford enoate $\mathbf{9}(7.0 \mathrm{~g}, 73 \%)$ as a colorless oil; $R_{f} 0.59$ (20\% EtOAc/hexanes); $[\alpha]^{22} \mathrm{D}^{-16.4}\left(c 0.17, \mathrm{CHCl}_{3}\right) ;{ }^{1} \mathrm{H}$ NMR $\left(\mathrm{CDCl}_{3}\right) \delta 7.39-7.65$ (m, 10H), $6.83(\mathrm{dd}, J=15.7,4.1 \mathrm{~Hz}, 1 \mathrm{H}), 6.11(\mathrm{dd}, J=15.7,1.9, \mathrm{~Hz}, 1 \mathrm{H}), 4.41(\mathrm{~m}, 1 \mathrm{H}), 4.18$ $(\mathrm{q}, J=7.2 \mathrm{~Hz}, 2 \mathrm{H}), 3.75(\mathrm{dd}, J=10.2,4.0 \mathrm{~Hz}, 1 \mathrm{H}), 3.54(\mathrm{dd}, J=10.2,7.2, \mathrm{~Hz}, 1 \mathrm{H}), 2.73(\mathrm{~d}$, $J=4.1 \mathrm{~Hz}, 1 \mathrm{H}), 1.27(\mathrm{t}, J=7.2 \mathrm{~Hz}, 3 \mathrm{H}), 1.06(\mathrm{~s}, 9 \mathrm{H}) ;{ }^{13} \mathrm{C} \mathrm{NMR}\left(\mathrm{CDCl}_{3}\right) \delta 166.3,145.8,135.6$, $132.8,130.1,127.9,127.8,122.0,71.5,67.0,60.5,26.9,19.3,14.3$; HRMS $m / z$ (ESI) calcd for $\mathrm{C}_{23} \mathrm{H}_{30} \mathrm{O}_{4} \mathrm{SiNa}(\mathrm{M}+\mathrm{Na})^{+} 421.1805$, found 421.1805 .

Ethyl (2E,4S)-5-(tert-butyldiphenylsilanyloxy)-4-methoxymethoxy-2-pentenoate (1)-To a solution of $9(1.36 \mathrm{~g}, 3.42 \mathrm{mmol})$ in $\mathrm{CH}_{2} \mathrm{Cl}_{2}(80 \mathrm{~mL})$ at $0^{\circ} \mathrm{C}$ was added $i$ - $\mathrm{Pr}_{2} \mathrm{NEt}$ $(4.3 \mathrm{~g}, 33.3 \mathrm{mmol})$ followed by the dropwise addition of chloro(methoxy)methane (1.34 g, $16.6 \mathrm{mmol}$ ). The resulting solution was stirred for $20 \mathrm{~h}$ while it was allowed to warm to room temperature. The reaction mixture was quenched with sat. $\mathrm{NH}_{4} \mathrm{Cl}(30 \mathrm{~mL})$. The aqueous phase was extracted with ether $(3 \times 50 \mathrm{~mL})$. The combined organic layers were washed with brine, dried $\left(\mathrm{MgSO}_{4}\right)$ and evaporated to afford dark yellow oil. The crude material was presorbed on silica gel and purified by column chromatography (5\% - 20\% EtOAc/hexanes) to afford enoate $1(1.2 \mathrm{~g}, 85 \%)$ as a colorless oil; $R_{f} 0.64\left(20 \%\right.$ EtOAc/hexanes); $[\alpha]^{21}{ }_{\mathrm{D}} 12.3(c 1.7$, $\left.\mathrm{CHCl}_{3}\right) ;{ }^{1} \mathrm{H} \mathrm{NMR}\left(\mathrm{CDCl}_{3}\right) \delta 7.38-7.69(\mathrm{~m}, 10 \mathrm{H}), 6.85(\mathrm{dd}, J=15.7,5.5 \mathrm{~Hz}, 1 \mathrm{H}), 6.06(\mathrm{dd}$, $J=15.7,1.4 \mathrm{~Hz}, 1 \mathrm{H}), 4.72(\mathrm{~d}, J=6.6 \mathrm{~Hz}, 1 \mathrm{H}), 4.65(\mathrm{~d}, J=6.6 \mathrm{~Hz}, 1 \mathrm{H}), 4.32(\mathrm{~m}, 1 \mathrm{H}), 4.16(\mathrm{q}$, 
$J=7.1 \mathrm{~Hz}, 2 \mathrm{H}), 3.71(\mathrm{dd}, J=10.5,6.6 \mathrm{~Hz}, 1 \mathrm{H}), 3.63(\mathrm{dd}, J=10.7,5.2 \mathrm{~Hz}, 1 \mathrm{H}), 3.35(\mathrm{~s}, 3 \mathrm{H})$, $1.26(\mathrm{t}, J=7.1 \mathrm{~Hz}, 3 \mathrm{H}), 1.05(\mathrm{~s}, 9 \mathrm{H}) ;{ }^{13} \mathrm{C} \mathrm{NMR}\left(\mathrm{CDCl}_{3}\right) \delta 166.2,145.2,135.7,133.2,129.9$, 127.8, 122.9, 95.3, 76.0, 66.1, 60.5, 55.7, 26.8, 19.3, 14.3; HRMS $m / z$ (ESI) calcd for $\mathrm{C}_{25} \mathrm{H}_{34} \mathrm{O}_{5} \mathrm{SiNa}(\mathrm{M}+\mathrm{Na})^{+}$465.2067, found 465.2063.

Methyl (2E,4S)-4-benzyloxy-5-(tert-butyldiphenylsilanyloxy)-2-pentenoate (2)To a solution of diol $\mathbf{1 0}^{14 \mathrm{~b}}(3.15 \mathrm{~g}, 3.7 \mathrm{mmol})$ in dry methanol $(150 \mathrm{~mL})$ at $0{ }^{\circ} \mathrm{C}$ was added $\mathrm{NaIO}_{4}(0.96 \mathrm{~g}, 4.5 \mathrm{mmol})$. The resulting suspension was vigorously stirred for $24 \mathrm{~h}$ at room temperature. The precipitate was filtered and solution was concentrated under reduced pressure. The residue was dissolved in ether $(50 \mathrm{~mL})$ and the formed precipitate was filtered. The ether fraction was evaporated under reduced pressure to give viscous oil. The residue was dissolved in dry $\mathrm{CH}_{2} \mathrm{Cl}_{2}(100 \mathrm{~mL})$. To this solution at $-78^{\circ} \mathrm{C}$ was added methyl

(triphenylphosphoranylidene)acetate $(2.6 \mathrm{~g}, 8.0 \mathrm{mmol})$ in one portion. The resulting mixture was stirred for $28 \mathrm{~h}$ while it was allowed to warm to room temperature. Water $(100 \mathrm{~mL})$ was added to the reaction mixture, the two layers were separated, and the aqueous layer was extracted with $\mathrm{CH}_{2} \mathrm{Cl}_{2}(3 \times 50 \mathrm{~mL})$. The combined organic layers were washed with brine, dried $\left(\mathrm{MgSO}_{4}\right)$, and evaporated under reduced pressure. The crude olefin $(E: Z=7: 1)$ was presorbed on silica gel and purified by column chromatography ( $2 \%-5 \%$ EtOAc/hexanes) to afford enoate $2(3.08 \mathrm{~g}, 88 \%)$ as a colorless oil; $R_{f} 0.4\left(12 \%\right.$ EtOAc/hexanes); $[\alpha]^{21}{ }_{\mathrm{D}} 16.4(c$ $\left.1, \mathrm{CHCl}_{3}\right) ;{ }^{1} \mathrm{H} \mathrm{NMR}\left(\mathrm{CDCl}_{3}\right) \delta 7.76-7.65(\mathrm{~m}, 5 \mathrm{H}), 7.47-7.30(\mathrm{~m}, 10 \mathrm{H}), 6.93(\mathrm{dd}, J=15.7$, $5.8 \mathrm{~Hz}, 1 \mathrm{H}), 6.12(\mathrm{dd}, J=15.7,1.4 \mathrm{~Hz}, 1 \mathrm{H}), 4.64(\mathrm{~d}, J=11.8 \mathrm{~Hz}, 1 \mathrm{H}), 4.51(\mathrm{~d}, J=11.8 \mathrm{~Hz}$, $1 \mathrm{H}), 4.14(\mathrm{q}, J=5.0 \mathrm{~Hz}, 1 \mathrm{H}), 3.82(\mathrm{dd}, J=10.7,6.3 \mathrm{~Hz}, 1 \mathrm{H}), 3.76(\mathrm{~s}, 3 \mathrm{H}), 3.71(\mathrm{dd}, J=10.7$, $5.0 \mathrm{~Hz}, 1 \mathrm{H}), 1.07(\mathrm{~s}, 9 \mathrm{H}) ;{ }^{13} \mathrm{C} \mathrm{NMR}\left(\mathrm{CDCl}_{3}\right) \delta 166.6,145.9,138.1,135.7,134.9,133.2,129.9$, 129.7, 128.5, 127.8, 127.7, 122.7, 78.9, 71.7, 66.1, 51.7, 26.9, 19.3; HRMS $m / z$ (ESI) calcd for $\mathrm{C}_{29} \mathrm{H}_{34} \mathrm{O}_{4} \mathrm{SiNa}(\mathrm{M}+\mathrm{Na})^{+}$497.2118, found 497.2123.

Methyl (2E,4S)-4,5-dibenzyloxy-2-pentenoate (3)-To a solution of diol $11^{14 \mathrm{c}}(2.01$ $\mathrm{g}, 3.7 \mathrm{mmol})$ in dry methanol $(150 \mathrm{~mL})$ at $0{ }^{\circ} \mathrm{C}$ was added $\mathrm{NaIO}_{4}(0.94 \mathrm{~g}, 4.4 \mathrm{mmol})$. The resulting suspension was vigorously stirred for $24 \mathrm{~h}$ at room temperature. The precipitate was filtered and solution was concentrated under reduced pressure. The residue was dissolved in ether $(50 \mathrm{~mL})$ and the formed precipitate was filtered. The ether fraction was evaporated under reduced pressure to give viscous oil. The residue was dissolved in dry $\mathrm{CH}_{2} \mathrm{Cl}_{2}(100 \mathrm{~mL})$. To this solution at $-78{ }^{\circ} \mathrm{C}$ was added methyl (triphenylphosphoranylidene)acetate $(2.7 \mathrm{~g}, 8.1$ $\mathrm{mmol}$ ) in one portion. The resulting mixture was stirred for $10 \mathrm{~h}$ while it was allowed to warm to room temperature. Water $(100 \mathrm{~mL})$ was added, the two layers were separated, and the aqueous layer was extracted with $\mathrm{CH}_{2} \mathrm{Cl}_{2}(3 \times 100 \mathrm{~mL})$. The combined organic layers were washed with brine, dried $\left(\mathrm{MgSO}_{4}\right)$, and evaporated under reduced pressure. The crude olefin $(E: Z=8: 1)$ was presorbed on silica gel and purified by column chromatography $(5 \%-10 \%$ EtOAc/hexanes) to afford enoate $3(1.92 \mathrm{~g}, 80 \%)$ as a colorless oil; $R_{f} 0.3$ (35\% EtOAc/ hexanes); $[\alpha]^{28}{ }_{\mathrm{D}} 22.6\left(c 1, \mathrm{CHCl}_{3}\right) ;{ }^{1} \mathrm{H}$ NMR $\left(\mathrm{CDCl}_{3}\right) \delta 7.45-7.20(\mathrm{~m}, 10 \mathrm{H}), 6.94(\mathrm{dd}, J=$ $15.7,5.5 \mathrm{~Hz}, 1 \mathrm{H}), 6.16(\mathrm{dd}, J=16.0,1.4 \mathrm{~Hz}, 1 \mathrm{H}), 4.68(\mathrm{~d}, J=12.1 \mathrm{~Hz}, 1 \mathrm{H}), 4.58(\mathrm{~s}, 2 \mathrm{H}), 4.54$ $(\mathrm{d}, J=12.1 \mathrm{~Hz}, 1 \mathrm{H}), 4.25(\mathrm{q}, J=5.0 \mathrm{~Hz}, 1 \mathrm{H}), 3.77(\mathrm{~s}, 3 \mathrm{H}), 3.61(\mathrm{t}, J=6.3 \mathrm{~Hz}, 2 \mathrm{H}) ;{ }^{13} \mathrm{C} \mathrm{NMR}$ $\left(\mathrm{CDCl}_{3}\right) \delta 166.6,145.6,138.0,137.9,128.5,127.9,127.8,127.7,122.8,73.6,72.2,71.7,51.8$; HRMS $\mathrm{m} / z$ (ESI) calcd for $\mathrm{C}_{20} \mathrm{H}_{22} \mathrm{O}_{4} \mathrm{Na}(\mathrm{M}+\mathrm{Na})^{+} 349.1410$, found 349.1419.

Methyl (2Z,4S)-4-benzyloxy-5-(tert-butyldiphenylsilanyloxy)-2-pentenoate (5)To a solution of diol $10^{14 \mathrm{~b}}(3.15 \mathrm{~g}, 3.7 \mathrm{mmol})$ in dry methanol $(150 \mathrm{~mL})$ at $0{ }^{\circ} \mathrm{C}$ was added $\mathrm{NaIO}_{4}(0.96 \mathrm{~g}, 4.5 \mathrm{mmol})$. The resulting suspension was vigorously stirred for $24 \mathrm{~h}$ at room temperature. The precipitate was filtered and solution was concentrated under reduced pressure. The residue was dissolved in ether $(50 \mathrm{~mL})$ and the formed precipitate was filtered. The ether fraction was evaporated under reduced pressure to give viscous oil. The residue was dissolved in dry methanol $(100 \mathrm{~mL})$. To this solution at $0{ }^{\circ} \mathrm{C}$ was added methyl 
(triphenylphosphoranylidene)acetate $(2.6 \mathrm{~g}, 8 \mathrm{mmol})$ in one portion. The resulting mixture was stirred for $10 \mathrm{~h}$ while it was allowed to warm to room temperature. The solvent was evaporated under reduced pressure. The residue was dissolved in $\mathrm{CH}_{2} \mathrm{Cl}_{2}(100 \mathrm{~mL})$, washed with water $(3 \times 50 \mathrm{~mL})$, brine, dried $\left(\mathrm{MgSO}_{4}\right)$, and evaporated under reduced pressure. The crude olefin $(E: Z=1: 2)$ was presorbed on silica gel and purified by column chromatography $(2 \%-5 \%$ EtOAc/hexanes) to afford enoate $5(2.08 \mathrm{~g}, 61 \%)$ as a colorless oil; $R_{f} 0.47(12 \%$ EtOAc/ hexanes); $\left[\alpha{ }^{28}{ }_{\mathrm{D}} 16.4\left(c 1, \mathrm{CHCl}_{3}\right) ;{ }^{1} \mathrm{H} \mathrm{NMR}\left(\mathrm{CDCl}_{3}\right) \delta 7.73-7.68(\mathrm{~m}, 5 \mathrm{H}), 7.45-7.28(\mathrm{~m}\right.$, $10 \mathrm{H}), 6.25(\mathrm{dd}, J=11.8,8.5 \mathrm{~Hz}, 1 \mathrm{H}), 5.95(\mathrm{dd}, J=11.8,1.1 \mathrm{~Hz}, 1 \mathrm{H}), 5.32-5.25(\mathrm{~m}, 1 \mathrm{H}), 4.63$ $(\mathrm{d}, J=11.8 \mathrm{~Hz}, 1 \mathrm{H}), 4.57(\mathrm{~d}, J=11.8 \mathrm{~Hz}, 1 \mathrm{H}), 3.85(\mathrm{dd}, J=10.5,5.8 \mathrm{~Hz}, 1 \mathrm{H}), 3.8(\mathrm{dd}, J=$ $10.5,4.4 \mathrm{~Hz}, 1 \mathrm{H}), 3.69(\mathrm{~s}, 3 \mathrm{H}), 1.06(\mathrm{~s}, 9 \mathrm{H}) ;{ }^{13} \mathrm{C} \mathrm{NMR}\left(\mathrm{CDCl}_{3}\right) \delta 166.2,148.1,138.7,135.8$, 135.7, 133.6, 133.5, 129.7, 128.4, 127.8, 127.7, 127.6, 122.1, 76.2, 71.7, 66.2, 51.4, 26.9, 19.4; HRMS $m / z$ (ESI) calcd for $\mathrm{C}_{29} \mathrm{H}_{34} \mathrm{O}_{4} \mathrm{SiNa}(\mathrm{M}+\mathrm{Na})^{+} 497.2118$, found 497.2127.

Methyl (2Z,4S)-4,5-dibenzyloxy-2-pentenoate (6) ${ }^{27}$-To a solution of diol $11^{14 c}$ $(2.01 \mathrm{~g}, 3.7 \mathrm{mmol})$ in dry methanol $(150 \mathrm{~mL})$ at $0{ }^{\circ} \mathrm{C}$ was added $\mathrm{NaIO}_{4}(0.94 \mathrm{~g}, 4.4 \mathrm{mmol})$. The resulting suspension was vigorously stirred for $24 \mathrm{~h}$ at room temperature. The precipitate was filtered and solution was concentrated under reduced pressure. The residue was dissolved in ether $(50 \mathrm{~mL})$ and the formed precipitate was filtered. The ether fraction was evaporated under reduced pressure to give viscous oil. The residue was dissolved in dry methanol (100 $\mathrm{mL}$ ). To this solution at $0{ }^{\circ} \mathrm{C}$ was added methyl (triphenylphosphoranylidene)acetate $(2.7 \mathrm{~g}$, $8.1 \mathrm{mmol}$ ) in one portion. The resulting mixture was stirred for $10 \mathrm{~h}$ while it was allowed to warm to room temperature. The solvent was evaporated under reduced pressure. The residue was dissolved in $\mathrm{CH}_{2} \mathrm{Cl}_{2}(100 \mathrm{~mL})$, washed with water $(3 \times 50 \mathrm{~mL})$, brine, dried $\left(\mathrm{MgSO}_{4}\right)$, and evaporated under reduced pressure. The crude olefin $(E: Z=1: 8)$ was presorbed on silica gel and purified by column chromatography (5\% - 10\% EtOAc/hexanes) to afford enoate 6 $(1.56 \mathrm{~g}, 65 \%)$ as a colorless oil.

\section{B. Arylcuprate Reactions}

General procedure for arylcuprate addition-A few drops of a required aryl bromide were added to crushed $\mathrm{Mg}$ turnings $(0.17 \mathrm{~g}, 7.03 \mathrm{mmol})$ in THF $(10 \mathrm{~mL})$ under nitrogen atmosphere. Once the reaction started the solution warmed up and slightly darkened. The rest of the aryl bromide $(7.03 \mathrm{mmol}$ total) was added dropwise to allow a gentle reaction. The reaction mixture was allowed to cool to room temperature and then cannulated to a slurry of $\mathrm{CuI}(0.67 \mathrm{~g}, 3.52 \mathrm{mmol})$ in THF $(10 \mathrm{~mL})$ at $-78^{\circ} \mathrm{C}$. The mixture was stirred at $-78{ }^{\circ} \mathrm{C}$ for 40 min (in the synthesis of $12 \mathrm{e}$ the mixture was stirred at $0{ }^{\circ} \mathrm{C}$ for $2 \mathrm{~h}$, as no trans-metallation occurred at $\left.-78^{\circ} \mathrm{C}\right)$. $\mathrm{Me}_{3} \mathrm{SiCl}(0.38 \mathrm{~g}, 7.03 \mathrm{mmol})$ and a corresponding enoate $(0.703 \mathrm{mmol}$ in $10 \mathrm{~mL}$ of THF) were added sequentially dropwise at $-78^{\circ} \mathrm{C}$. The yellow-brown suspension was stirred overnight while slowly warming up to room temperature. At this time reactions of trans enoates 1, 2, 3, 4 were finished. In the addition reactions of cis enoates 5, 6, 7 the reaction mixtures were stirred for additional $24-48 \mathrm{~h}$ until the starting material disappeared. The reaction mixture was quenched with a mixture of conc. $\mathrm{NH}_{4} \mathrm{OH}$ and sat. $\mathrm{NH}_{4} \mathrm{Cl}(1: 9,30 \mathrm{~mL})$ and extracted with ether $(3 \times 30 \mathrm{~mL})$. The combined organic layers were washed with brine, dried with $\mathrm{MgSO}_{4}$ and concentrated under reduced pressure. The residue was absorbed on silica gel and purified by column chromatography (5\%-30\% EtOAc/hexanes) to yield corresponding addition product as an oil.

Compound 12a-80\%, $R_{f} 0.58\left(20 \%\right.$ EtOAc/hexanes); $[\alpha]^{21}{ }_{\mathrm{D}}-43.9\left(c 0.5, \mathrm{CHCl}_{3}\right) ;{ }^{1} \mathrm{H}$ $\operatorname{NMR}\left(\mathrm{CDCl}_{3}\right) \delta 7.19-7.60(\mathrm{~m}, 15 \mathrm{H}), 4.68(\mathrm{~d}, J=6.9 \mathrm{~Hz}, 1 \mathrm{H}), 4.51(\mathrm{~d}, J=6.9 \mathrm{~Hz}, 1 \mathrm{H}), 3.97$ $(\mathrm{q}, J=7.2 \mathrm{~Hz}, 2 \mathrm{H}), 3.75(\mathrm{~m}, 1 \mathrm{H}), 3.46(\mathrm{~m}, 3 \mathrm{H}), 3.27(\mathrm{~s}, 3 \mathrm{H}), 2.97(\mathrm{dd}, J=15.6,5.2 \mathrm{~Hz}, 1 \mathrm{H})$, $2.64(\mathrm{dd}, J=15.6,10.2 \mathrm{~Hz}, 1 \mathrm{H}), 1.08(\mathrm{t}, J=7.2 \mathrm{~Hz}, 3 \mathrm{H}), 1.03(\mathrm{~s}, 9 \mathrm{H}) ;{ }^{13} \mathrm{C} \mathrm{NMR}\left(\mathrm{CDCl}_{3}\right) \delta$ $172.8,141.3,135.5,133.2,129.8,128.5,127.8,126.9,96.4,81.0,63.9,60.0,56.0,43.1,37.2$, 
26.8, 19.2, 14.0; HRMS $m / z$ (ESI) calcd for $\mathrm{C}_{31} \mathrm{H}_{40} \mathrm{O}_{5} \mathrm{SiNa}(\mathrm{M}+\mathrm{Na})^{+}$543.2537, found 543.2530 .

Compound 12b-78\%, $R_{f} 0.45\left(20 \%\right.$ EtOAc/hexanes); $[\alpha]^{21}{ }_{\mathrm{D}}-45.7\left(c 0.2, \mathrm{CHCl}_{3}\right) ;{ }^{1} \mathrm{H}$ $\operatorname{NMR}\left(\mathrm{CDCl}_{3}\right) \delta 6.76-7.60(\mathrm{~m}, 14 \mathrm{H}), 4.52(\mathrm{~d}, J=6.9 \mathrm{~Hz}, 1 \mathrm{H}), 4.69(\mathrm{~d}, J=6.9 \mathrm{~Hz}, 1 \mathrm{H}), 3.98$ (q, $J=7.0 \mathrm{~Hz}, 2 \mathrm{H}), 3.77(\mathrm{~s}, 3 \mathrm{H}), 3.75(\mathrm{~m}, 1 \mathrm{H}), 3.42(\mathrm{~m}, 3 \mathrm{H}), 3.29(\mathrm{~s}, 3 \mathrm{H}), 2.96(\mathrm{dd}, J=15.4$, $5.2 \mathrm{~Hz}, 1 \mathrm{H}), 2.59(\mathrm{dd}, J=15.4,10.5 \mathrm{~Hz}, 1 \mathrm{H}), 1.07(\mathrm{t}, J=7.0 \mathrm{~Hz}, 3 \mathrm{H}), 1.03(\mathrm{~s}, 3 \mathrm{H}) ;{ }^{13} \mathrm{C} \mathrm{NMR}$ $\left(\mathrm{CDCl}_{3}\right) \delta 172.7,158.4,135.7,135.6,133.4,133.2,129.7,129.3,127.7,116.1,114.8,113.8$, 96.4, 81.1, 63.7, 60.2, 56.1, 55.3, 42.6, 37.4, 26.9, 19.3, 14.2; HRMS $\mathrm{m} / z$ (ESI) calcd for $\mathrm{C}_{32} \mathrm{H}_{42} \mathrm{O}_{6} \mathrm{SiNa}\left(\mathrm{M}+\mathrm{Na}^{+}\right)$573.2642, found 573.2630.

Compound 12c-79\%, $R_{f} 0.48\left(20 \%\right.$ EtOAc/hexanes); $[\alpha]^{21}{ }_{\mathrm{D}}-37.8\left(\mathrm{c} 0.6, \mathrm{CHCl}_{3}\right) ;{ }^{1} \mathrm{H}$ $\operatorname{NMR}\left(\mathrm{CDCl}_{3}\right) \delta 7.63-6.92(\mathrm{~m}, 14 \mathrm{H}), 4.67(\mathrm{~d}, J=6.9 \mathrm{~Hz}, 1 \mathrm{H}), 4.50(\mathrm{~d}, J=6.9 \mathrm{~Hz}, 1 \mathrm{H}), 3.99$ $(\mathrm{q}, J=7.1 \mathrm{~Hz}, 2 \mathrm{H}), 3.71(\mathrm{~m}, 1 \mathrm{H}), 3.52(\mathrm{~m}, 3 \mathrm{H}), 3.27(\mathrm{~s}, 3 \mathrm{H}), 2.97(\mathrm{dd}, J=15.7,4.9 \mathrm{~Hz}, 1 \mathrm{H})$, $2.60(\mathrm{dd}, J=15.7,10.5 \mathrm{~Hz}, 1 \mathrm{H}), 1.07(\mathrm{t}, J=7.1 \mathrm{~Hz}, 3 \mathrm{H}), 1.03(\mathrm{~s}, 3 \mathrm{H}) ;{ }^{13} \mathrm{C} \mathrm{NMR}\left(\mathrm{CDCl}_{3}\right) \delta$ 172.4, 136.9, 135.7, 135.5, 133.3, 133.1, 129.9, 129.8, 127.7, 115.4, 115.1, 96.4, 80.8, 63.6, $60.3,56.1,42.6,37.1,31.0,26.9,19.2,14.2$; HRMS $m / z$ (ESI) calcd for $\mathrm{C}_{31} \mathrm{H}_{39} \mathrm{FO}_{5} \mathrm{SiNa}(\mathrm{M}$ $+\mathrm{Na})^{+}$561.2443, found 561.2422.

Compound 12d-75\%, $R_{f} 0.46\left(20 \%\right.$ EtOAc/hexanes); $[\alpha]^{21} \mathrm{D}-35.6\left(\mathrm{c} 0.2, \mathrm{CHCl}_{3}\right) ;{ }^{1} \mathrm{H}$ $\operatorname{NMR}\left(\mathrm{CDCl}_{3}\right) \delta 7.59-7.30(\mathrm{~m}, 10 \mathrm{H}), 6.66(\mathrm{~m}, 3 \mathrm{H}), 5.91(\mathrm{~s}, 2 \mathrm{H}), 4.70(\mathrm{~d}, J=6.9 \mathrm{~Hz}, 1 \mathrm{H})$, $4.53(\mathrm{~d}, J=6.9 \mathrm{~Hz}, 1 \mathrm{H}), 4.0(\mathrm{q}, J=7.2 \mathrm{~Hz}, 2 \mathrm{H}), 3.69(\mathrm{~m}, 1 \mathrm{H}), 3.51(\mathrm{~m}, 3 \mathrm{H}), 2.94(\mathrm{dd}, J=15.4$, $4.95 \mathrm{~Hz}, 1 \mathrm{H}), 2.56(\mathrm{dd}, J=15.4,10.2, \mathrm{~Hz}, 1 \mathrm{H}), 1.12(\mathrm{t}, J=7.2 \mathrm{~Hz}, 3 \mathrm{H}), 1.03(\mathrm{~s}, 9 \mathrm{H}) ;{ }^{13} \mathrm{C} \mathrm{NMR}$ $\left(\mathrm{CDCl}_{3}\right) \delta 172.5,147.8,146.3,135.6,133.7,129.7,127.7,121.8,108.3,108.0,100.9,96.5$, 81.7, 64.0, 60.3, 56.0, 35.8, 34.7, 31.7, 26.9, 25.3, 22.7, 14.2; HRMS $\mathrm{m} / z$ (ESI) calcd for $\mathrm{C}_{32} \mathrm{H}_{40} \mathrm{O}_{7} \mathrm{SiNa}(\mathrm{M}+\mathrm{Na})^{+}$587.2435, found 587.2421.

Compound 12e-76\%, $R_{f} 0.38\left(20 \%\right.$ EtOAc/hexanes); $[\alpha]^{21}{ }_{\mathrm{D}}-26.8\left(\mathrm{c} 0.4, \mathrm{CHCl}_{3}\right) ;{ }^{1} \mathrm{H}$ NMR $\left(\mathrm{CDCl}_{3}\right) \delta 7.63-7.28(\mathrm{~m}, 10 \mathrm{H}), 6.73(\mathrm{~m}, 3 \mathrm{H}), 4.69(\mathrm{~d}, J=6.9 \mathrm{~Hz}, 1 \mathrm{H}), 4.52(\mathrm{~d}, J=6.9$ $\mathrm{Hz}, 1 \mathrm{H}), 3.99(\mathrm{q}, J=7.7 \mathrm{~Hz}, 2 \mathrm{H}), 3.85(\mathrm{~s}, 3 \mathrm{H}), 3.78(\mathrm{~s}, 3 \mathrm{H}), 3.73(\mathrm{~m}, 1 \mathrm{H}), 3.52(\mathrm{~m}, 3 \mathrm{H}), 3.30$ (s, 3H), $2.97(\mathrm{dd}, J=15.4,4.9 \mathrm{~Hz}, 1 \mathrm{H}), 2.61(\mathrm{dd}, J=15.4,10.5 \mathrm{~Hz}, 1 \mathrm{H}), 1.11(\mathrm{t}, J=7.7 \mathrm{~Hz}$, $3 \mathrm{H}), 1.03(\mathrm{~s}, 9 \mathrm{H}) ;{ }^{13} \mathrm{C} \mathrm{NMR}\left(\mathrm{CDCl}_{3}\right) \delta 172.7,148.7,147.7,135.6,133.7,133.4,133.1,129.8$, 27.7, 120.3, 111.5, 111.0, 96.4, 81.0, 63.7, 60.2, 56.1, 55.9, 43.0, 37.6, 26.9, 19.3, 14.2; HRMS $\mathrm{m} / z$ (ESI) calcd for $\mathrm{C}_{33} \mathrm{H}_{44} \mathrm{O}_{7} \mathrm{SiNa}(\mathrm{M}+\mathrm{Na})^{+} 603.2748$, found 603.2764 .

Compound 12f-75\%, $R_{f} 0.56\left(40 \%\right.$ EtOAc/hexanes); $[\alpha]^{21}{ }_{\mathrm{D}}-27.2\left(\mathrm{c} 0.2, \mathrm{CHCl}_{3}\right) ;{ }^{1} \mathrm{HNMR}$ $\left(\mathrm{CDCl}_{3}\right) \delta 7.61-7.30(\mathrm{~m}, 10 \mathrm{H}), 6.38(\mathrm{~m}, 2 \mathrm{H}), 5.92(\mathrm{~s}, 2 \mathrm{H}), 4.69(\mathrm{~d}, J=6.7 \mathrm{~Hz}, 1 \mathrm{H}), 4.52(\mathrm{~d}$, $J=6.7 \mathrm{~Hz}, 1 \mathrm{H}), 4.02(\mathrm{q}, J=6.9 \mathrm{~Hz}, 2 \mathrm{H}), 3.79(\mathrm{~s}, 3 \mathrm{H}), 3.68(\mathrm{~m}, 1 \mathrm{H}), 3.50(\mathrm{~m}, 3 \mathrm{H}), 3.29(\mathrm{~s}$, $3 \mathrm{H}), 2.94(\mathrm{dd}, J=15.4,4.9 \mathrm{~Hz}, 1 \mathrm{H}), 2.56(\mathrm{dd}, J=15.4,10.2 \mathrm{~Hz}, 1 \mathrm{H}), 1.13(\mathrm{t}, J=6.9 \mathrm{~Hz}, 3 \mathrm{H})$, 1.04 (s, $9 \mathrm{H}) ;{ }^{13} \mathrm{C} \mathrm{NMR}\left(\mathrm{CDCl}_{3}\right) \delta 172.5,148.7,143.3,135.8,135.7,135.5,133.9,133.3,133.1$, 129.7, 127.7, 107.7, 102.1, 101.4, 96.4, 80.9, 63.7, 60.3, 56.4, 56.1, 43.4, 37.4, 26.8, 19.2, 14.2; HRMS $m / z$ (ESI) calcd for $\mathrm{C}_{33} \mathrm{H}_{42} \mathrm{O}_{8} \mathrm{SiNa}(\mathrm{M}+\mathrm{Na})^{+} 617.2541$, found 617.2551 .

Compound 13a-88\%; $R_{f} 0.35$ (15\% EtOAc/hexanes); $[\alpha]^{25}{ }_{\mathrm{D}}^{-49.2}\left(c 1, \mathrm{CHCl}_{3}\right) ;{ }^{1} \mathrm{H} \mathrm{NMR}$ $\left(\mathrm{CDCl}_{3}\right) \delta 7.66-7.57(\mathrm{~m}, 5 \mathrm{H}), 7.47-7.22(\mathrm{~m}, 15 \mathrm{H}), 4.72(\mathrm{~d}, J=11.6 \mathrm{~Hz}, 1 \mathrm{H}), 4.44(\mathrm{~d}, J=$ $11.6 \mathrm{~Hz}, 1 \mathrm{H}), 3.73-3.52(\mathrm{~m}, 4 \mathrm{H}), 3.49(\mathrm{~s}, 3 \mathrm{H}), 3.02(\mathrm{dd}, J=16.0,4.9 \mathrm{~Hz}, 1 \mathrm{H}), 2.71(\mathrm{dd}, J=$ $16.0,8.8 \mathrm{~Hz}, 1 \mathrm{H}), 1.09(\mathrm{~s}, 9 \mathrm{H}) ;{ }^{13} \mathrm{C} \mathrm{NMR}\left(\mathrm{CDCl}_{3}\right) \delta 173.2,141.7,138.6,135.7,135.6,135.4$, 134.9, 133.5, 133.3, 129.7, 128.6, 128.4, 127.9, 127.8, 127.6, 126.9, 83.4, 72.7, 63.5, 51.5, 43.6, 37.4, 26.9, 19.3; HRMS $m / z$ (ESI) calcd for $\mathrm{C}_{35} \mathrm{H}_{40} \mathrm{O}_{4} \mathrm{SiNa}(\mathrm{M}+\mathrm{Na})^{+} 575.2588$, found 575.2598 . 
Compound 13d-93\%; $R_{f} 0.4$ (15\% EtOAc/hexanes); $[\alpha]^{26}{ }_{\mathrm{D}}-49.4\left(c 1, \mathrm{CHCl}_{3}\right) ;{ }^{1} \mathrm{H}$ NMR $\left(\mathrm{CDCl}_{3}\right) \delta 7.61-7.55(\mathrm{~m}, 5 \mathrm{H}), 7.42-7.26(\mathrm{~m}, 10 \mathrm{H}), 6.67(\mathrm{~d}, J=8.0 \mathrm{~Hz}, 3 \mathrm{H}), 5.92(\mathrm{~s}, 2 \mathrm{H})$, $4.67(\mathrm{~d}, J=11.6 \mathrm{~Hz}, 1 \mathrm{H}), 4.39(\mathrm{~d}, J=11.6 \mathrm{~Hz}, 1 \mathrm{H}), 3.67-3.43(\mathrm{~m}, 4 \mathrm{H}), 3.48(\mathrm{~s}, 3 \mathrm{H}), 2.92$ $(\mathrm{dd}, J=16.0,4.9 \mathrm{~Hz}, 1 \mathrm{H}), 2.60(\mathrm{dd}, J=16.0,9.4 \mathrm{~Hz}, 1 \mathrm{H}), 1.04(\mathrm{~s}, 9 \mathrm{H}) ;{ }^{13} \mathrm{C} \mathrm{NMR}\left(\mathrm{CDCl}_{3}\right)$ $\delta$ 173.0, 147.6, 146.3 138.5, 135.7, 135.6, 135.4, 133.4, 133.2, 129.7, 128.3, 127.8, 127.7, $127.5,121.5,108.5,108.2,100.9,83.4,72.7,63.6,51.4,43.3,37.5,26.9,19.2$; HRMS m/z (ESI) calcd for $\mathrm{C}_{36} \mathrm{H}_{40} \mathrm{O}_{6} \mathrm{SiNa}(\mathrm{M}+\mathrm{Na})^{+}$619.2486, found 619.2495.

Compound 13f-82\%; $R_{f} 0.6$ (30\% EtOAc/hexanes); $[\alpha]^{25}$ D $-47.9\left(c 1, \mathrm{CHCl}_{3}\right) ;{ }^{1} \mathrm{H}$ NMR $\left(\mathrm{CDCl}_{3}\right) \delta 7.62-7.56(\mathrm{~m}, 5 \mathrm{H}), 7.43-7.26(\mathrm{~m}, 10 \mathrm{H}), 6.39(\mathrm{~s}, 2 \mathrm{H}), 5.95(\mathrm{~s}, 2 \mathrm{H}), 4.68(\mathrm{~d}, J=$ $11.6 \mathrm{~Hz}, 1 \mathrm{H}), 4.39(\mathrm{~d}, J=11.6 \mathrm{~Hz}, 1 \mathrm{H}), 3.77(\mathrm{~s}, 3 \mathrm{H}), 3.74-3.44(\mathrm{~m}, 4 \mathrm{H}), 3.50(\mathrm{~s}, 3 \mathrm{H}), 2.92$ $(\mathrm{dd}, J=16.0,4.9 \mathrm{~Hz}, 1 \mathrm{H}), 2.60(\mathrm{dd}, J=16.0,9.4 \mathrm{~Hz}, 1 \mathrm{H}), 1.05(\mathrm{~s}, 9 \mathrm{H}) ;{ }^{13} \mathrm{C} \mathrm{NMR}\left(\mathrm{CDCl}_{3}\right)$ $\delta 173.0,148.8,143.4,138.5,136.3,135.7,135.6,134.0,133.5,133.1,129.7,128.5,128.3$, 127.8, 127.7, 127.7, 127.6, 107.8, 101.9, 101.4, 83.4, 72.6, 63.5, 56.5, 51.5, 43.6, 37.3, 26.9, 19.3; HRMS $m / z$ (ESI) calcd for $\mathrm{C}_{37} \mathrm{H}_{42} \mathrm{O}_{7} \mathrm{SiNa}(\mathrm{M}+\mathrm{Na})^{+} 649.2592$, found 649.2569.

Epimeric mixture 14a 28_94\%; (anti:syn = 14.6:1); $R_{f} 0.45$ (30\% EtOAc/hexanes); selected ${ }^{1} \mathrm{H}$ NMR $\left(\mathrm{CDCl}_{3}\right)$ data for the anti-isomer $\delta 7.55-7.15(\mathrm{~m}, 15 \mathrm{H}), 4.80(\mathrm{~d}, J=11.6$ $\mathrm{Hz}, 1 \mathrm{H}), 4.55(\mathrm{~d}, J=11.6 \mathrm{~Hz}, 1 \mathrm{H}), 4.44(\mathrm{~s}, 2 \mathrm{H}), 3.81-3.73(\mathrm{~m}, 1 \mathrm{H}), 3.58-3.47(\mathrm{~m}, 1 \mathrm{H}), 3.50$ (s, 3H), 3.36 (dd, $J=10.5,5.2 \mathrm{~Hz}, 1 \mathrm{H}), 3.04$ (dd, $J=16.0,5.8 \mathrm{~Hz}, 1 \mathrm{H}), 2.64$ (dd, $J=16.0,9.1$ $\mathrm{Hz}, 1 \mathrm{H}) ; \mathrm{HRMS} m / z$ (ESI) calcd for $\mathrm{C}_{26} \mathrm{H}_{28} \mathrm{O}_{4} \mathrm{Na}(\mathrm{M}+\mathrm{Na})^{+} 427.1879$, found 427.1891.

\section{Stereochemistry Confirmation} (4R,5S)-5-Acetoxymetyl-4-phenyl-4,5-dihydro-2(3H)-furanone (19) ${ }^{\mathbf{1 6}}$

Method 1: To a solution of 12a (136 mg, $0.26 \mathrm{mmol})$ in $\mathrm{CH}_{2} \mathrm{Cl}_{2}(15 \mathrm{~mL})$ was added $\mathrm{Me}_{2} \mathrm{BBr}$ $\left(0.8 \mathrm{~mL}\right.$ of $1.6 \mathrm{M}$ solution in $\left.\mathrm{CH}_{2} \mathrm{Cl}_{2}\right)$ at $-78{ }^{\circ} \mathrm{C}$. The resulting mixture was stirred for $3 \mathrm{~h}$ at $-78{ }^{\circ} \mathrm{C}$. THF $(3 \mathrm{~mL})$ and sat. aq. $\mathrm{NaHCO}_{3}(1.5 \mathrm{~mL})$ was added to reaction mixture at $-78{ }^{\circ} \mathrm{C}$ and the temperature raised to room temperature. Ether $(50 \mathrm{~mL})$ was added to the mixture. The two layers were separated and the organic layer was washed with sat. $\mathrm{NH}_{4} \mathrm{Cl}$, brine, dried with $\mathrm{Na}_{2} \mathrm{SO}_{4}$ and evaporated. The crude residue was presorbed on silica gel and purified by column chromatography (10\% - 20\% EtOAc/hexane) to give pure intermediate 5-tert-

butyldiphenylsilyloxymethyl lactone $\mathbf{2 9}(65 \mathrm{mg}, 63 \%)$ as a colorless oil; $R_{f} 0.4(12 \%$ EtOAc/ hexanes); $[\alpha]^{21}{ }_{\mathrm{D}} 23.8\left(c 1, \mathrm{CHCl}_{3}\right) ;{ }^{1} \mathrm{H} \mathrm{NMR}\left(\mathrm{CDCl}_{3}\right) \delta 7.25-7.66(\mathrm{~m}, 15 \mathrm{H}), 4.51(\mathrm{~m}, 1 \mathrm{H})$, $3.94(\mathrm{dd}, J=2.8,11.6 \mathrm{~Hz}, 1 \mathrm{H}), 3.73(\mathrm{~m}, 2 \mathrm{H}), 3.09(\mathrm{dd}, J=9.4,17.8 \mathrm{~Hz}, 1 \mathrm{H}), 2.69(\mathrm{dd}, J=$ 8.0, $17.8 \mathrm{~Hz}, 1 \mathrm{H}), 1.06(\mathrm{~s}, 9 \mathrm{H}) ;{ }^{13} \mathrm{C} \mathrm{NMR}\left(\mathrm{CDCl}_{3}\right) \delta 176.2,140.7,135.7,135.6,130.0,129.2$, 127.9, 127.7, 127.0, 86.8, 63.7, 42.4, 37.4, 26.9, 19.3; HRMS m/z (ESI) calcd for $\mathrm{C}_{27} \mathrm{H}_{30} \mathrm{O}_{3} \mathrm{SiNa}\left(\mathrm{M}+\mathrm{Na}^{+}\right)$453.1856, found 453.1851.

To a solution of the lactone $29(25 \mathrm{mg}, 0.058 \mathrm{mmol})$ in THF $(1 \mathrm{~mL})$ at $0{ }^{\circ} \mathrm{C}$ was added TBAF $(0.29 \mathrm{~mL}$ of $1 \mathrm{M}$ solution in THF, $0.29 \mathrm{mmol})$. The resulting mixture was stirred for $1 \mathrm{~h}$ at $0{ }^{\circ}$ $\mathrm{C}$ and then aqueous sat. $\mathrm{NH}_{4} \mathrm{Cl}(1 \mathrm{~mL})$ was added. The aqueous phase was extracted with ether $(3 \times 5 \mathrm{~mL})$. The combined organic layers were dried with $\mathrm{Na}_{2} \mathrm{SO}_{4}$ and evaporated to give pure intermediate 5-hydroxymethyl lactone 30 ( $10.8 \mathrm{mg}, 96 \%)$. $R_{f} 0.4$ (35\% EtOAc/hexanes); $[\alpha]$ $22{ }_{\mathrm{D}} 28.3\left(c \mathrm{c} 0.68, \mathrm{CHCl}_{3}\right) ;{ }^{1} \mathrm{H}$ NMR $\left(\mathrm{CDCl}_{3}\right) \delta 7.39-7.16(\mathrm{~m}, 5 \mathrm{H}), 4.56-4.51(\mathrm{~m}, 1 \mathrm{H}), 4.10$ - $3.85(\mathrm{~m}, 1 \mathrm{H}), 3.81-3.56(\mathrm{~m}, 2 \mathrm{H}), 3.03(\mathrm{dd}, J=18.0,9.1 \mathrm{~Hz}, 1 \mathrm{H}), 2.78(\mathrm{dd}, J=18.0,9.6 \mathrm{~Hz}$, $1 \mathrm{H}), 2.44(\mathrm{t}, J=6.3 \mathrm{~Hz}, 1 \mathrm{H}) ;{ }^{13} \mathrm{C} \mathrm{NMR}\left(\mathrm{CDCl}_{3}\right) \delta 176.0,139.2,129.3,127.9,127.3,87.0$, 62.0, 42.1, 37.3; HRMS m/z (ESI) calcd for $\mathrm{C}_{11} \mathrm{H}_{12} \mathrm{O}_{3} \mathrm{Na}(\mathrm{M}+\mathrm{Na})^{+} 215.0678$, found 215.0679.

Lactone $30(15 \mathrm{mg}, 0.078 \mathrm{mmol})$ was dried by co-evaporating with toluene $(5 \times 1 \mathrm{~mL})$ and dissolved in anhydrous pyridine $(1 \mathrm{~mL})$. To this solution at $0{ }^{\circ} \mathrm{C}$ was added acetic anhydride ( $80 \mathrm{mg}, 0.78 \mathrm{mmol})$. The resulting mixture was allowed to warm to room temperature and the reaction mixture was stirred for $5 \mathrm{~h}$. The mixture was extracted with ether $(3 \times 5 \mathrm{~mL})$. The 
combined organic layers were washed with water $(5 \mathrm{~mL})$, dried $\left(\mathrm{MgSO}_{4}\right)$ and evaporated. The residue was presorbed on silica gel and purified by column chromatography (5\%-10\% EtOAc/ hexanes) to afford lactone $19^{16}(12 \mathrm{mg}, \mathbf{6 6 \%})$.

Method 2: To a stirred solution of phenyl addition product 13a $(54.6 \mathrm{mg}, 0.1 \mathrm{mmol})$ in a mixture of dioxane-water $(1: 1,5 \mathrm{~mL})$ was added $10 \% \mathrm{Pd} / \mathrm{C}(5 \mathrm{mg}, 0.004 \mathrm{mmol})$. The suspension was stirred for 3 days under $\mathrm{H}_{2}$ atmosphere at atmospheric pressure. The catalyst was filtered off with a celite pad and solution was concentrated under reduced pressure. The residue was dissolved in ether $(30 \mathrm{~mL})$, washed with water $(3 \times 20 \mathrm{~mL})$, brine, dried $\left(\mathrm{MgSO}_{4}\right)$, and evaporated under reduced pressure. The crude residue was presorbed on silica gel and purified by column chromatography (10\% - 20\% EtOAc/hexane) to give pure lactone 29 (35 mg, $67 \%$ ), which was treated as in method 1 to provide 19.

Method 3: To a stirred solution of the epimeric mixture 14a (14:1, $0.48 \mathrm{~g}, 1.2 \mathrm{mmol})$ in dioxane-water $(1: 1,25 \mathrm{~mL})$ was added $10 \% \mathrm{Pd} / \mathrm{C}(25 \mathrm{mg}, 0.02 \mathrm{mmol})$. The suspension was stirred for 3 days under $\mathrm{H}_{2}$ atmosphere at atmospheric pressure. The catalyst was filtered off with a celite pad and solution was concentrated under reduced pressure. The residue was dissolved in ether $(50 \mathrm{~mL})$, washed with water $(3 \times 20 \mathrm{~mL})$, brine, dried $\left(\mathrm{MgSO}_{4}\right)$, and evaporated under reduced pressure to give trans lactone $\mathbf{3 0}(0.24 \mathrm{~g}, 90 \%)$ with the traces of the corresponding cis lactone. This mixture was further treated as in method 1 to obtain $\mathbf{1 9}$ with only traces of $\mathbf{2 0 .}$

(4R,5R)-5-Methyl-4-phenyl-4,5-dihydro-2(3H)-furanone (21) and (4S,5R)-5-Methyl-4phenyl- 4,5-dihydro-2(3H)-furanone (22) $\frac{\mathbf{1 7}}{}$ : To a stirred solution of the epimeric mixture $(6: 1)$ of $\mathbf{1 5 a}(0.4 \mathrm{~g}, 1.2 \mathrm{mmol})$ in dioxane-water $(1: 1,25 \mathrm{~mL})$ was added $10 \% \mathrm{Pd} / \mathrm{C}(25 \mathrm{mg}$, $0.02 \mathrm{mmol}$ ). The suspension was stirred for 3 days under $\mathrm{H}_{2}$ atmosphere at atmospheric pressure. The catalyst was filtered off with a celite pad and solution was concentrated under reduced pressure. The residue was dissolved in ether $(50 \mathrm{~mL})$, washed with water $(3 \times 20 \mathrm{~mL})$, brine, dried $\left(\mathrm{MgSO}_{4}\right)$, and evaporated under reduced pressure to give lactones $21^{17}(0.174 \mathrm{~g}$, $76 \%)$ and $22^{16}(0.029 \mathrm{~g}, 13 \%)$.

\section{Supplementary Material}

Refer to Web version on PubMed Central for supplementary material.

\section{Acknowledgment}

We thank Professor Patrick S. Mariano for his advice and help with the preparation of the manuscript. This work is supported by the National Institutes of Health (CA-99957 and RR-16480) under the AREA and BRIN/INBRE programs.

\section{References}

1. Krause, N. Modern Organocopper Chemistry. Wiley-VCH; Weinheim: 2002.

2(a). Deslongchamps, P. Stereoelectronic Effects in Organic Chemistry. Pergamon; Exeter, UK: 1983. p. 221-242. (b) Yamamoto K, Ogura H, Jukuta J.-i. Inoue H, Hamada K, Sugiyama Y, Yamada S. J. Org. Chem 1998;63:4449-4458. (c) Krause N, Hoffmann-Röder A. Synthesis 2001:171-196. (d) Sibi MP, Manyem S. Tetrahedron 2000;56:8033-8061.

3(a). For selected synthetic applications, see:Ziegler FE, Gilligan PJ. J. Org. Chem 1981;46:3874-3880. (b) Nemoto H, Ando M, Fukumoto K. Tetrahedron Lett 1990;31:6205-6208. (c) Hanessian S, Raghavan S. Bioorg. Med. Chem. Lett 1994;4:1697-1702. (d) Dominguez E, Carretero JC. Tetrahedron 1993;50:7557-7566. (e) Hanessian S, Gai Y, Wang W. Tetrahedron Lett 1996;37:7473-7476. (f) Horita K, Hachiya S, Ogihara K, Yoshida Y, Nagasawa M, Yonemitsu O. Heterocycles 1996;42:99-104. (g) Kocienski PJ, Narquizian R, Raubo P, Smith C, Boyle FT. 
Synlett 1998:869-872. (h) Ziegler FE, Wang Y. J. Org. Chem 1998;63:426-427. [PubMed: 11672025] (i) Ziegler FE, Wang Y. J. Org. Chem 1998;63:7920-7930. (j) Hanessian S, Ma J, Wang W. Tetrahedron Lett 1999;40:4627-4630. (k) Stoncius A, Mast CA, Sewald N. Tetrahedron: Asymmetry 2000;11:3849-3853. (1) Zhu B, Panek JS. Eur. J. Org. Chem 2001:1701-1714. (m) Hanessian S, Ma J. Tetrahedron Lett 2001;42:8785-8788. (n) Hanessian S, Ma J, Wang W. J. Am. Chem. Soc 2001;123:10200-10206. [PubMed: 11603969] (o) Nakamura S, Inagaki J, Sugimoto T, Ura Y, Hashimoto S. Tetrahedron 2002;58:10375-10386. (p) Powell SA, Tenenbaum JM, Woerpel KA. J. Am. Chem. Soc 2002;124:12648-12649. [PubMed: 12392397] (q) Hanessian S, Yang Y, Giroux S, Mascitti V, Ma JU, Raeppel F. J. Am. Chem. Soc 2003;125:13784-13792. [PubMed: 14599218] (r) Nadein ON, Kornienko A. Org. Lett 2004;6:831-834. [PubMed: 14986986] (s) Hanessian S, Mascitti V, Giroux S. Proc. Natl. Acad. Sci. U.S.A 2004;101:11996-12001. [PubMed: 15210988] (t) Hanessian S, Yun H, Hou Y, Tintelnot-Blomley M. J. Org. Chem 2005;70:67466756. [PubMed: 16095294]For further examples of anti-selective organocuprate additions, see refs 6,7 .

4. Reactions of allylcopper reagents seem to be an exception to the "anti-addition" rule, see:Nicolaou KC, Pavia MR, Seitz SP. J. Am. Chem. Soc 1981;103:1224-1226.

5. For demonstration of the importance of $\sigma^{*}$-orbital energies in determining the "large" group in Felkin model, see:Lodge EP, Heathcock CH. J. Am. Chem. Soc 1987;109:3353-3361.

6(a). For selected discussions of the modified Felkin-Anh model, see:Roush WR, Lesur BM. Tetrahedron Lett 1983;24:2231-2234. (b) Roush WR, Michaelides MR, Tai DF, Lesur BM, Chong WKM, Harris DJ. J. Am. Chem. Soc 1989;111:2984-2995. (c) Bernardi A, Cardani S, Poli G, Scolastico C. J. Org. Chem 1986;51:5041-5043. (d) Bernardi A, Cardani S, Pilati T, Poli G, Scolastico C, Villa R. J. Org. Chem 1988;53:1600-1607. (e) Cardani S, Poli G, Scolastico C, Villa R. Tetrahedron 1988;44:5929-5938. (f) Hanessian S, Sumi K. Synthesis 1991:1083-1089. (g) Nilsson K, Ullenius C. Tetrahedron 1994;50:13173-13180. (h) Raczko J. Tetrahedron: Asymmetry 1997;8:3821-3828. (i) Mengel A, Reiser O. Chem. Rev 1999;99:1191-1223. [PubMed: 11749444] (j) Manpadi M, Kornienko A. Tetrahedron Lett 2005;46:4433-4437.See also refs 7a,b,g.

7(a). For selected discussions of the Yamamoto model, see:Yamamoto Y, Nishii S, Ibuka T. J. Chem. Soc., Chem. Commun 1987:464-466. (b) Yamamoto Y, Chounan Y, Nishii S, Ibuka T, Kitahara H. J. Am. Chem. Soc 1992;114:7652-7660. (c) Dominguez E, Carretero JC. Tetrahedron Lett 1993;34:5803-5806. (d) Funaki I, Bell RPL, Thijs L, Zwanenburg B. Tetrahedron 1996;52:1225312274. (e) Hanessian S, Wang W, Gai Y, Olivier E. J. Am. Chem. Soc 1997;119:10034-10041. (f) Amigoni S, Schulz J, Martin L, LeFloch Y. Tetrahedron: Asymmetry 1997;8:1515-1518. (g) Chounan Y, Ono Y, Nishii S, Kitahara H, Ito S, Yamamoto Y. Tetrahedron 2000;56:2821-2831.See also refs 6f,g,h,i.

8(a). Cieplak AS, Tait BD, Johnson CR. J. Am. Chem. Soc 1989;111:8447-8462. (b) Cieplak AS. Chem. Rev 1999;99:1265-1336. [PubMed: 11749447]

9. Lessard J, Saunders JK, Viet MTP. Tetrahedron Lett 1982;23:2059-2062.

10. Houk KN, Moses SR, Wu YD, Rondan NG, Jager V, Schohe R, Fronczek FR. J. Am. Chem. Soc 1984;106:3880-3882.

11. For recent review, see:Nakamura E, Mori S. Angew. Chem., Int. Ed 2000;39:3750-3771.

12. A portion of this investigation has been reported, see ref. $3 r$. The remaining results will be detailed in future publications describing the synthetic pathways to the target natural products.

13. Bernardi A, Cardani S, Scolastico C, Villa R. Tetrahedron 1988;44:491-502.

14(a). Takano S, Kurotaki A, Takahashi M, Ogasawara K. Synthesis 1986:403-406. (b) Peters U, Bankova W, Welzel P. Tetrahedron 1987;43:3803-3816. (c) Bouzide A, Sauvé G, Sévigny G, Yelle J. Bioorg. Med. Chem. Lett 2003;13:3601-3605. [PubMed: 14505679]

15. Maryanoff BE, Reitz AB. Chem. Rev 1989;89:863-927.

16. Ha H-J, Yoon K-N, Lee S-Y, Park Y-S, Lim M-S, Yim Y-G. J. Org. Chem 1998;63:8062-8066.

17. Reissig H-U, Angert H. J. Org. Chem 1993;58:6280-6285.

18(a). Krauss SR, Smith SG. J. Am. Chem. Soc 1981;103:141-148. (b) Horiguchi Y, Komatsu M, Kuwajima I. Tetrahedron Lett 1989;30:7087-7090. (c) Matsuzawa S, Horiguchi Y, Nakamura E, Kuwajima I. Tetrahedron 1989;45:349-362. (d) Lipshutz BH, Dimock SH, James B. J. Am. Chem. Soc 1993;115:9283-9284. (e) Vellekoop AS, Smith RJ. J. Am. Chem. Soc 1994;116:2902-2913. (f) Krause N, Wagner R, Gerold A. J. Am. Chem. Soc 1994;116:381-382. (g) Dorigo AE, Wanner 
J, Schleyer PVR. Angew. Chem., Int. Ed 1995;34:476-478. (h) Bertz SH, Miao G, Rossiter BE, Snyder JP. J. Am. Chem. Soc 1995;117:11023-11024. (i) Frantz DE, Singleton DA, Snyder JP. J. Am. Chem. Soc 1997;119:3383-3384. (j) Canisius J, Gerold A, Krause N. Angew. Chem., Int. Ed 1999;38:1644-1646. (k) Frantz DF, Singleton DA. J. Am. Chem. Soc 2000;122:3288-3295. (1) Pfretzschner T, Kleemann L, Janza B, Harms K, Schrader T. Chem. Eur. J 2004;10:6048-6057. (m) Mori S, Uerdingen M, Krause N, Morokuma K. Angew. Chem., Int. Ed 2005;44:4715-4719.

19(a). Nakamura E, Mori S, Morokuma K. J. Am. Chem. Soc 1997;119:4900-4910. (b) Mori S, Nakamura E. Chem. Eur. J 1999;5:1534-1543. (c) Nakamura E, Yamanaka M. J. Am. Chem. Soc 1999;121:8941-8942.(d) Ref. 10. (e) Yamanaka M, Inagaki A, Nakamura E. J. Comput. Chem 2003;24:1401-1409. [PubMed: 12868105] (f) Nakanishi W, Yamanaka M, Nakamura E. J. Am. Chem. Soc 2005;127:1446-1453. [PubMed: 15686377] (g) Yoshikai N, Yamashita T, Nakamura E. Angew. Chem., Int. Ed 2005;44:4721-4723.

20. The first evidence for this pathway and its role in stereochemistry of organocopper addition reactions was disclosed by Corey and Boaz: Corey EJ, Boaz NW. Tetrahedron Lett 1984;26:6015-6018.

21(a). Barrett AGM, Weipert PD, Dhanak D, Husa RK, Lebold SA. J. Am. Chem. Soc 1991;113:98209824. (b) Burgess LE, Meyers AI. J. Am. Chem. Soc 1991;113:9858-9859. (c) Reetz MT, Kayser F, Harms K. Tetrahedron Lett 1992;33:3453-3456.

22(a). For selected examples, seeReetz MT, Rohrig D. Angew. Chem., Int. Ed 1989;28:1706-1709. (b) Jako I, Uiber P, Mann A, Taddei M, Wermuth CG. Tetrahedron Lett 1990;31:1011-1014.(c) Reference 5e. (d) Hanessian S, Wang W, Gai Y. Tetrahedron Lett 1996;37:7477-7480. (e) Hanessian S, Demont E, van Otterlo WAL. Tetrahedron Lett 2000;41:4999-5003. (f) Liang X, Andersch J, Bols M. J. Chem. Soc., Perkin Trans. 1 2001:2136-2157. (g) Flamant-Robin C, Wang Q, Sasaki NA. Tetrahedron Lett 2001;42:8483-8484. (h) Flamant-Robin C, Wang Q, Chiaroni A, Sasaki NA. Tetrahedron 2002;58:10475-10484. (i) Kumar S, Flamant-Robin C, Wang Q, Chiaroni A, Sasaki A. J. Org. Chem 2005;70:5946-5953. [PubMed: 16018690]

23. Amino groups are considerably more bulky than ethers, presumably due to the fact that the ether alkyl group can turn so as to point away from the steric congestion site. For example, various reported "A values" for -OMe and $-\mathrm{NMe}_{2}$ groups are 2.13-3.14 and 6.4-10.0 kJ/mol respectively. See in:ElielELWilenSHStereochemistry of Organic Compounds1994Wiley-InterscienceNew York

24. Karlstrom A, Sofia E, Bäckvall J-E. Chem. Eur. J 2001;7:1981-1989.

25. Yamanaka M, Kato S, Nakamura E. J. Am. Chem. Soc 2004;126:6287-6293. [PubMed: 15149226]

26. Arai M, Kawasuji T, Nakamura E. J. Org. Chem 1993;58:5121-5129.

27. Annunziata R, Cinquini M, Cozzi F. Tetrahedron 1987;43:2369-2380.

28. Characterization data of all epimeric mixtures obtained in this work can be found in the Supporting Information. 
(a) Felkin-Anh Model

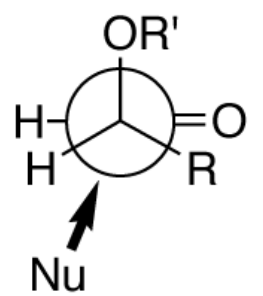

A

(b) Modified Felkin-Anh Model

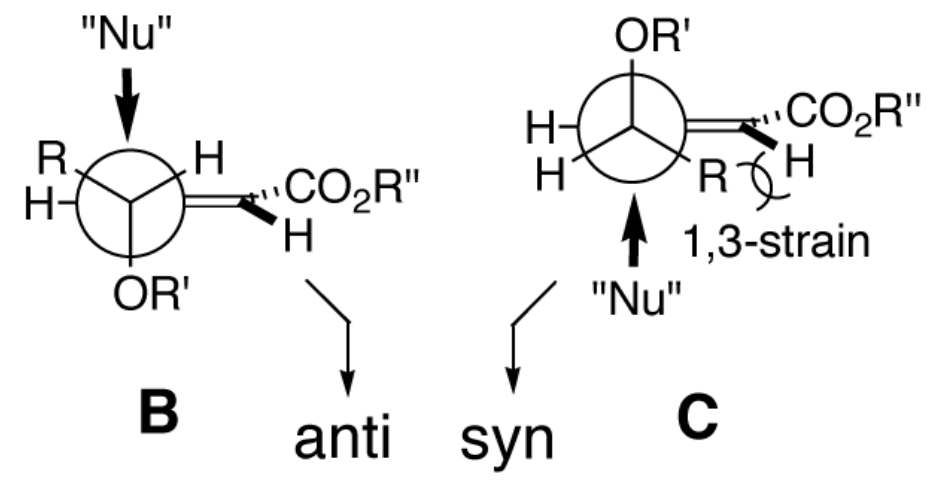

(c) Yamamoto Model

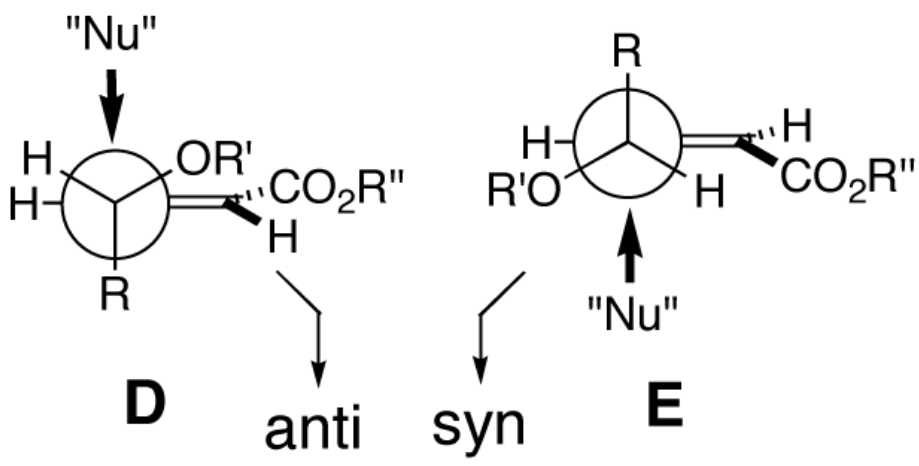

Figure 1.

Modified Felkin-Anh and Yamamoto interpretations of the stereochemical outcome of organocuprate conjugate addition to $\gamma$-alkoxy- $\alpha, \beta$-enoates. 
<smiles>O[C@H]1C=C2CCN3Cc4cc5c(cc4[C@@H]([C@H]1O)[C@H]23)OCO5</smiles>

Lycorine<smiles>O=C1N[C@H]2[C@H](O)[C@H](O)[C@@H](O)[C@H](O)[C@@H]2c2cc3c(c(O)c21)OCO3</smiles>

Pancratistatin<smiles></smiles><smiles>CN1CCC2=C[C@H](O)[C@H]3OC(=O)c4cc5c(cc4[C@H]3[C@@H]21)OCO5</smiles>

Hippeastrine<smiles>C1CC1</smiles>

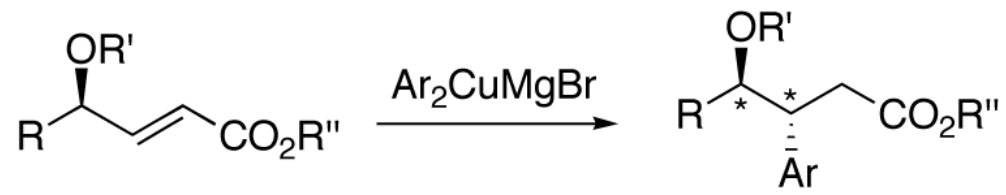

Figure 2.

Anti-selective arylcuprate conjugate addition to $\gamma$-alkoxy- $\alpha, \beta$-enoates as a solution to the stereochemical challenges presented by selected Amaryllidaceae constituents. 

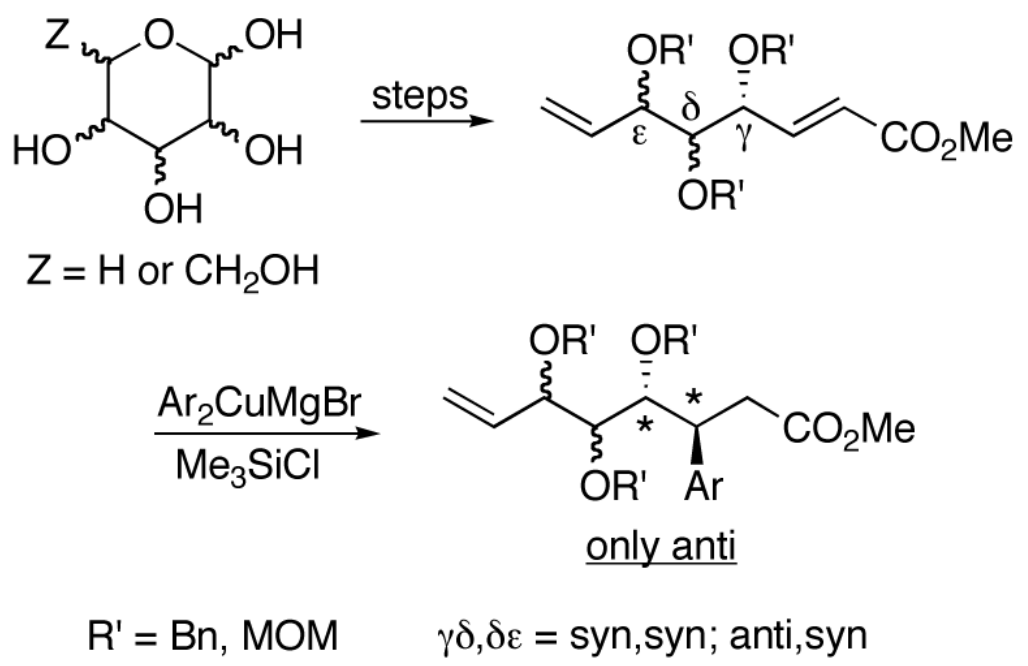

Figure 3.

Highly anti-selective arylcuprate conjugate addition reactions of carbohydrate-derived $\gamma, \delta, \varepsilon$ trialkoxy- $\alpha, \beta$-enoates. 
<smiles>CCOC(=O)/C=C/C(COC)OCC</smiles>

1<smiles>CC(=O)/C=C/[C@H](CO[PbH3])Cc1ccccc1</smiles>

2<smiles>[O+]OC=CCC(O)CO</smiles>

3<smiles>CC(=O)C=CC(C)OCc1ccccc1</smiles>

4

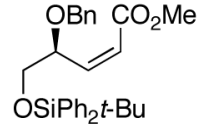

5<smiles>COC(=O)C=CC(C)OC(C)=CC(Cc1ccccc1)OCc1ccccc1</smiles>

6

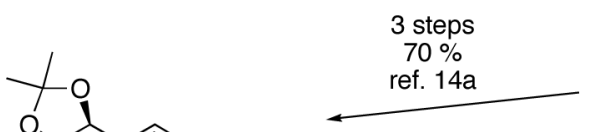

8<smiles>OCC(O)[C@@H](O)[C@@H](O)[C@H](O)CO</smiles>

D - mannitol

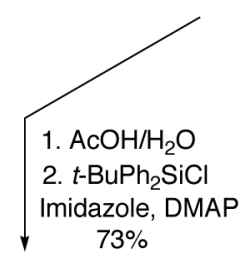<smiles>CCOC(=O)/C=C/C(O)CC</smiles>
$\mathrm{OSiPh}_{2} t$-Bu

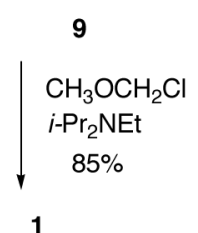

$t-\mathrm{BuPh}_{2} \mathrm{SiO}$

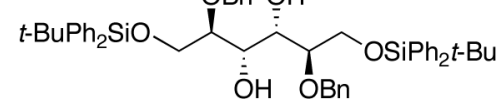

10
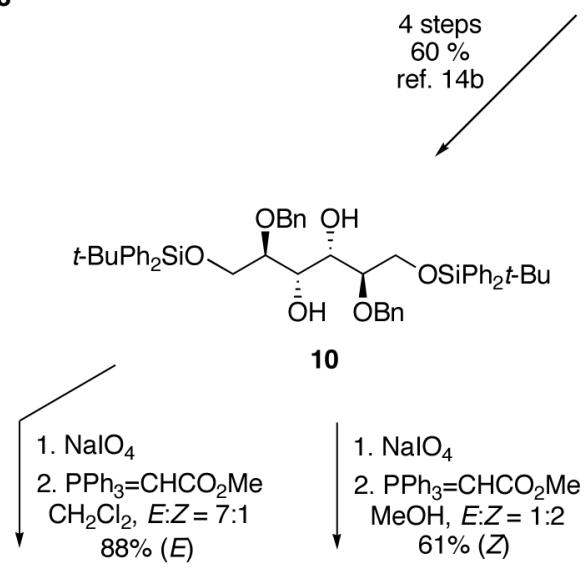

2

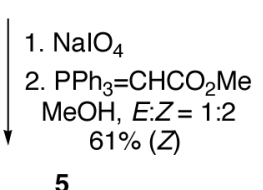

1. $\mathrm{NaIO}_{4}$ $61 \%(Z)$

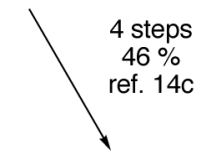<smiles>O[C@H](COCc1ccccc1)[C@@H](O)[C@@H](O)[C@H](Cc1ccccc1)OCc1ccccc1</smiles>

11

Figure 4.

Preparation of trans and cis $\alpha, \beta$-enoates with a single $\gamma$-alkoxy stereocenter. 


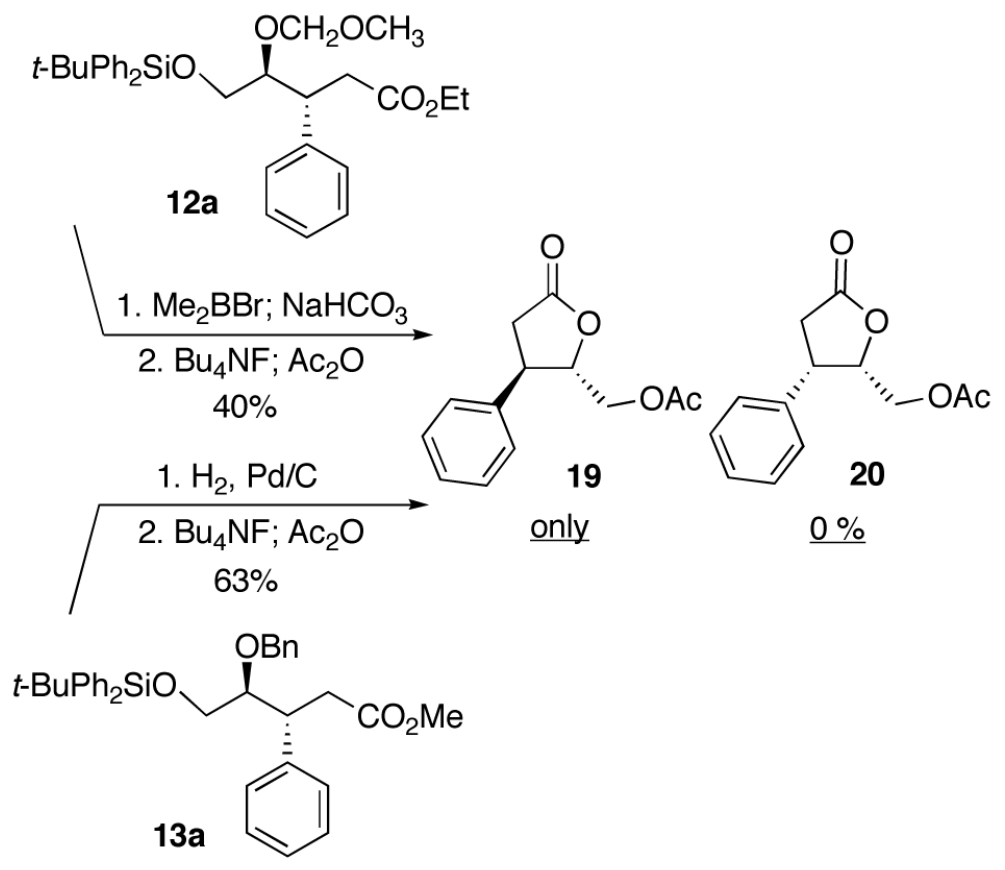

Figure 5.

Confirmation of anti-stereochemistry for the phenyl addition products 12a and 13a. 

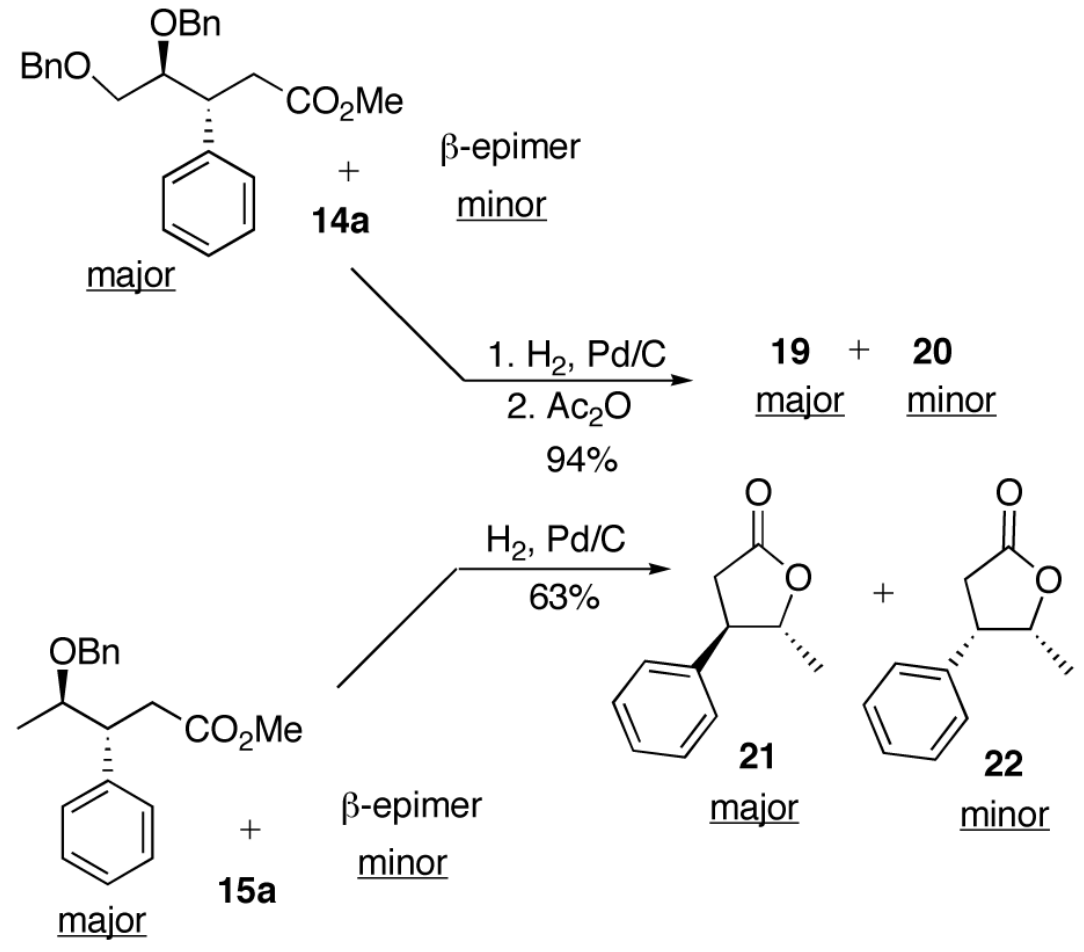

Figure 6.

Confirmation of stereochemistry for the major and minor phenyl addition products 14a and 15 . 

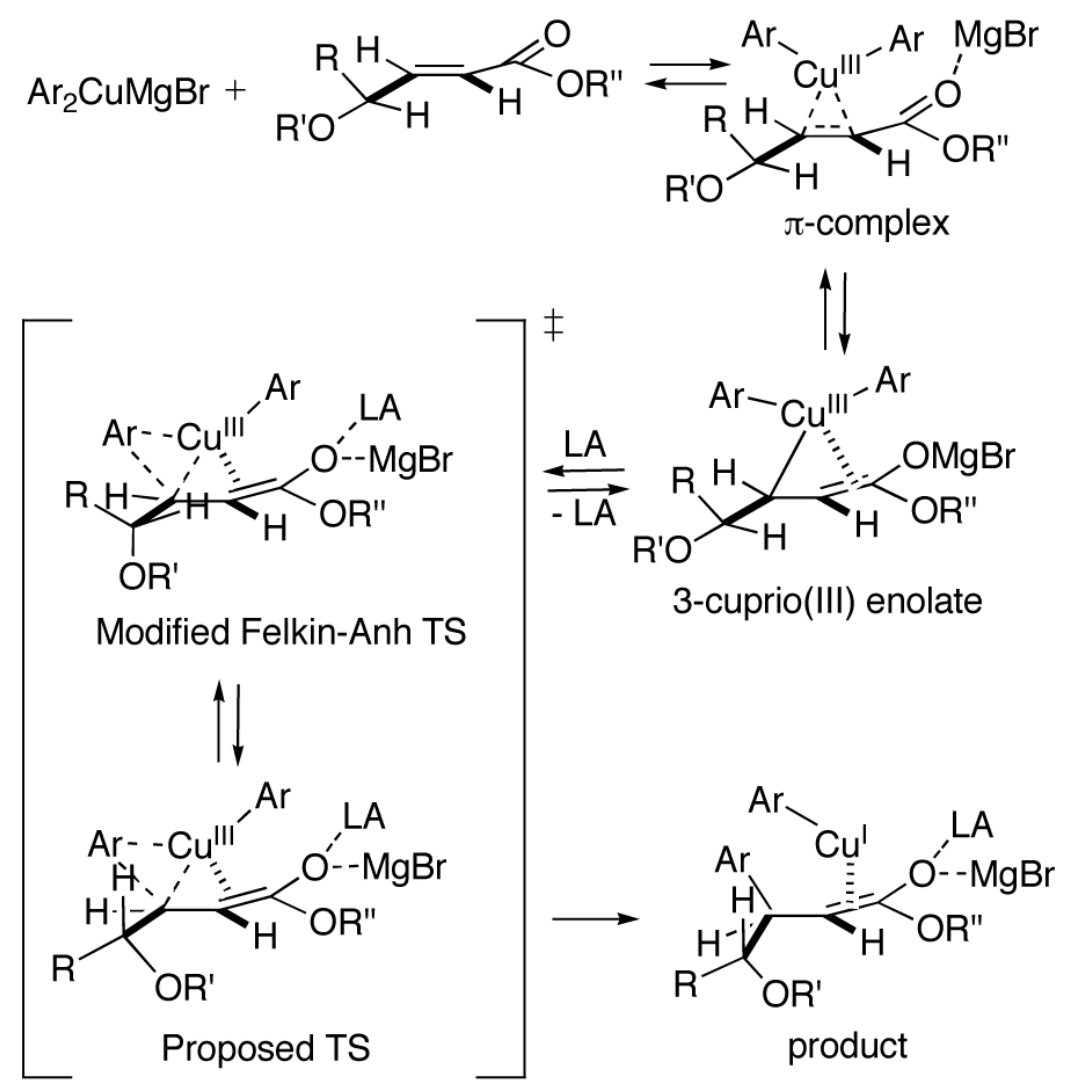

Figure 7.

Summary of experimental and theoretical mechanistic studies of organocopper conjugate addition reaction as adapted for the case of $\gamma$-alkoxy- $\alpha, \beta$-enoates. 
<smiles>[R]O[C@@H](O)/C=C/C(=O)O</smiles><smiles></smiles>

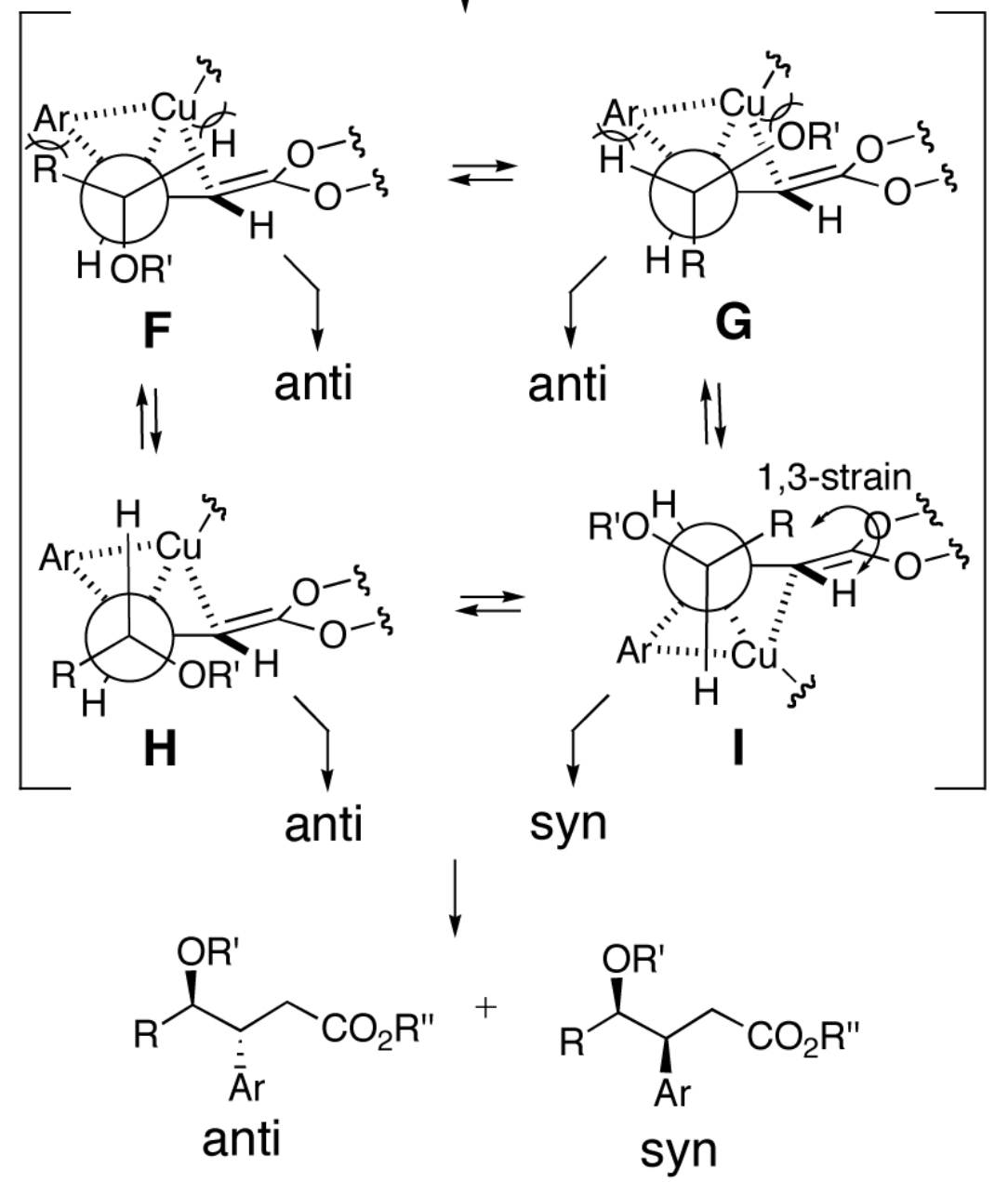

Figure 8.

Inadequacy of the Felkin-Anh and Yamamoto models $(\mathbf{F}$ and $\mathbf{G})$ and the proposed reductive elimination-based transition state conformations ( $\mathbf{H}$ and $\mathbf{I})$. 
(a)<smiles>[R]C(C=C(NC=O)OCC)[NH2+]CC</smiles>

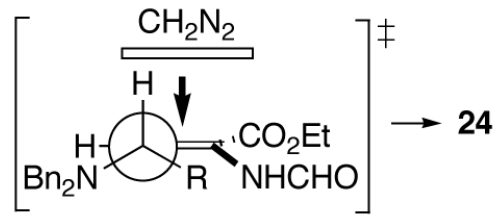

23

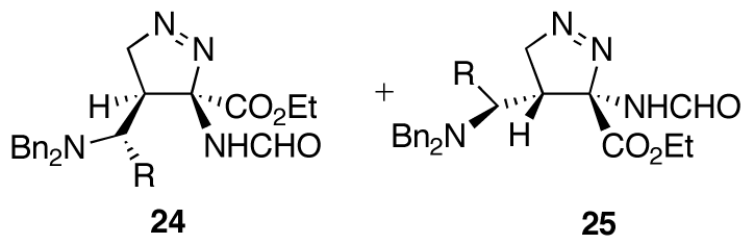

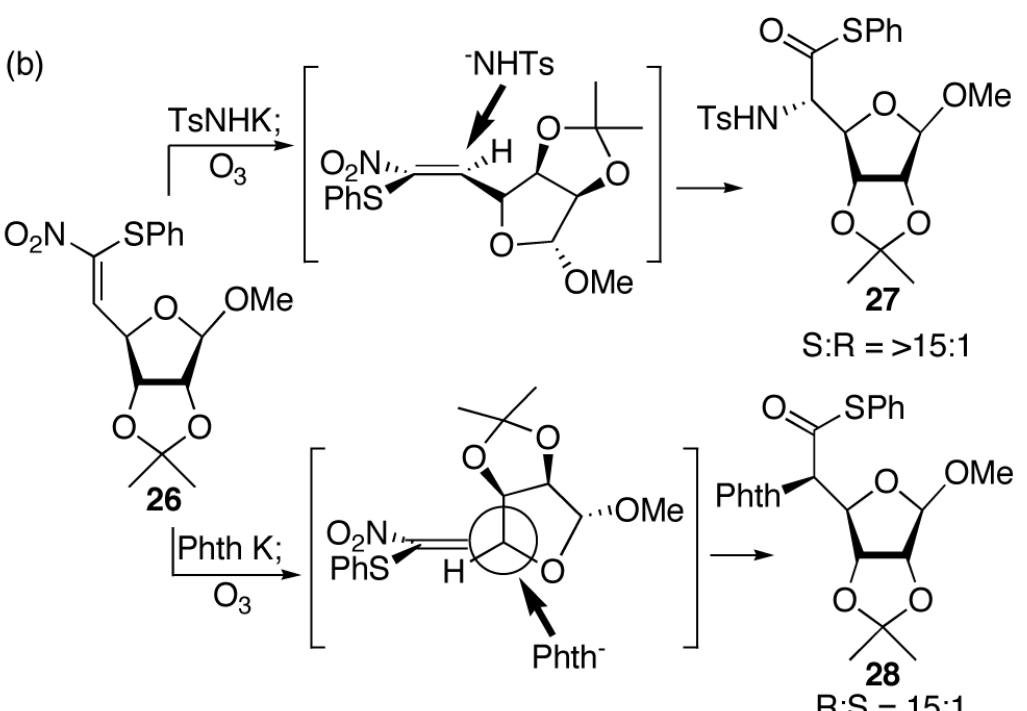

Figure 9.

The "flat" approach model proposed by Reetz and coworkers $21 \mathrm{c}$ and the aerofoil long-range steric congestion invoked by Barrett and coworkers. ${ }^{21 a}$ 
<smiles>[R]C(O)/C=C\C(=O)O[Na]</smiles>

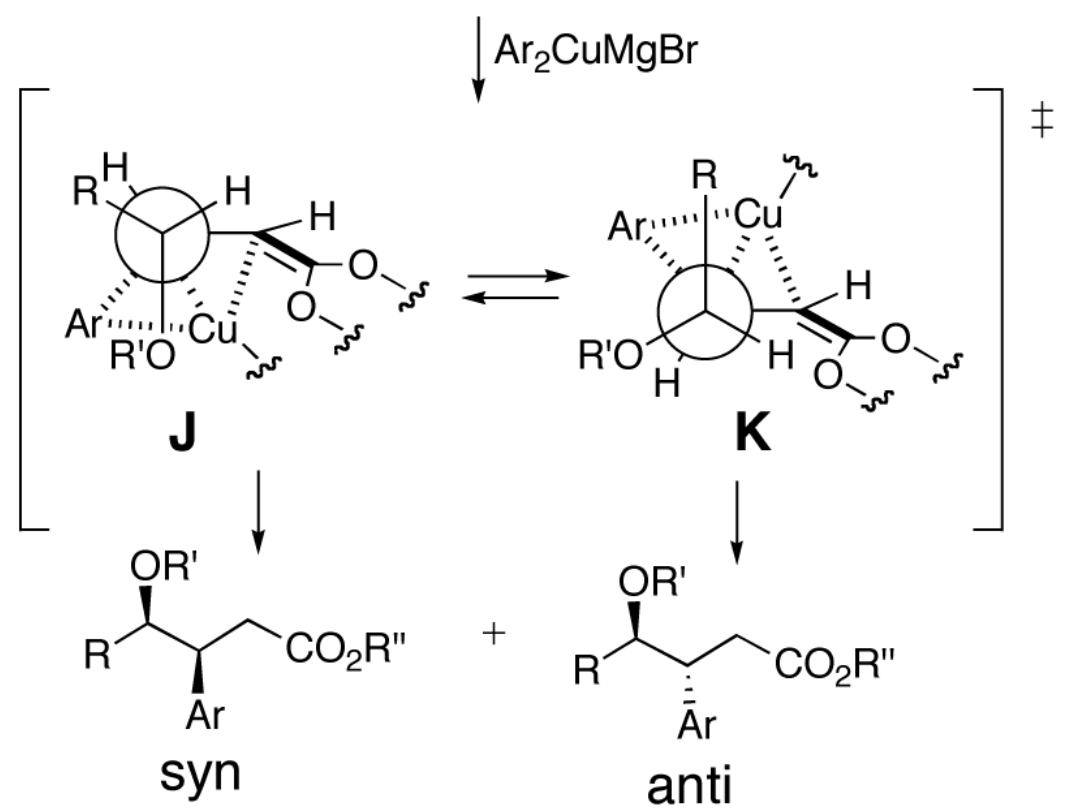

Figure 10.

Possible additional transition states that may result from reactions of cis enoates. 

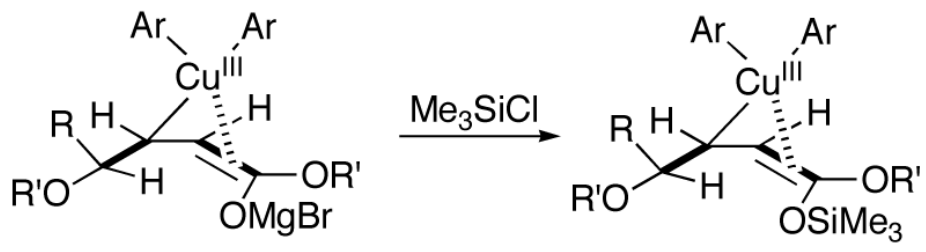

3-cuprio(III) enolate
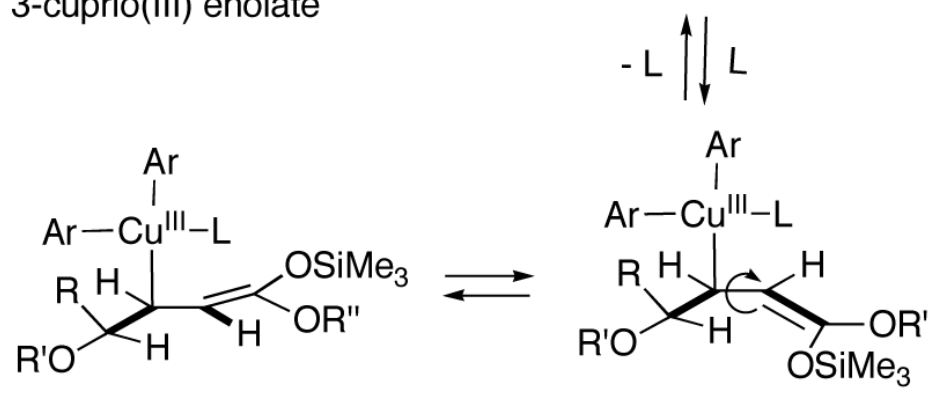

$L \uparrow \downarrow-L$
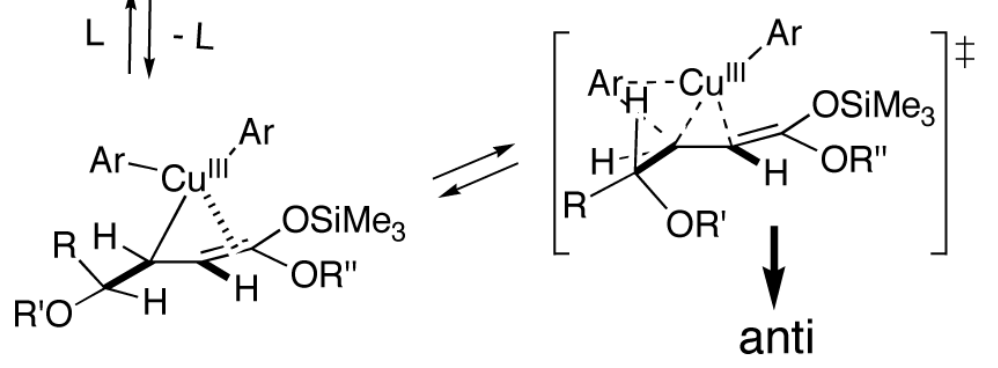

Figure 11.

Alternative mechanism for cis $\rightarrow$ trans isomerization of $\gamma$-akoxy- $\alpha, \beta$-enoates with the assistance of $\mathrm{Me}_{3} \mathrm{SiCl}$. 


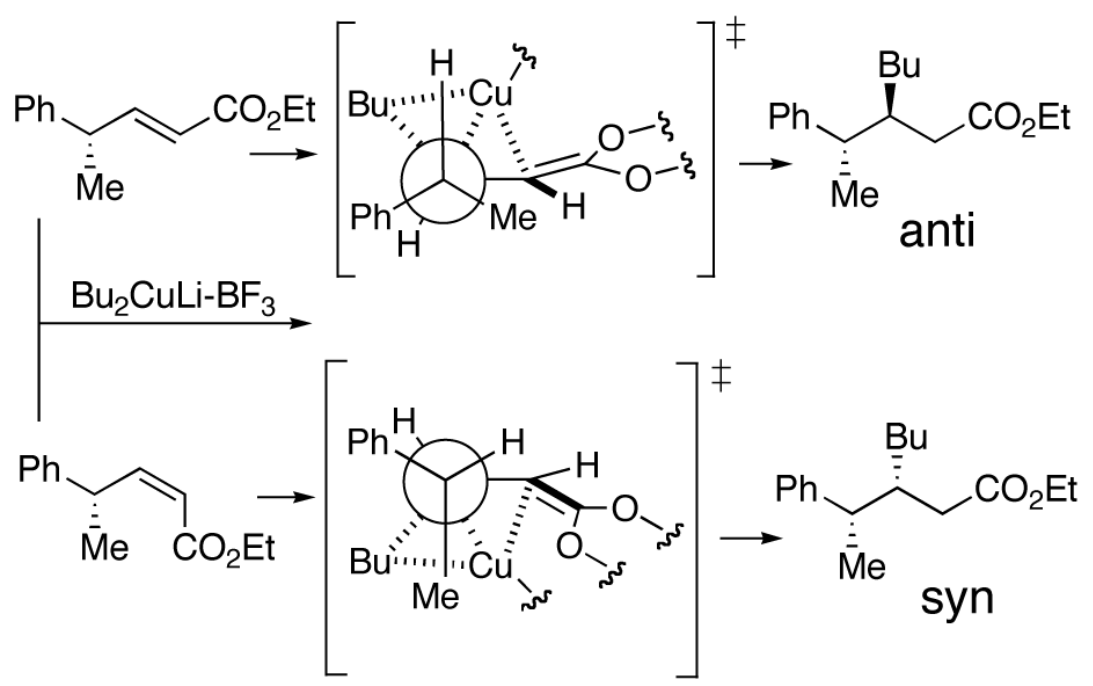

Figure 12.

Stereochemistry reversal as the enoate double bond geometry is changed from trans to cis observed by Yamamoto and coworkers. $7 \mathrm{~g}$ 


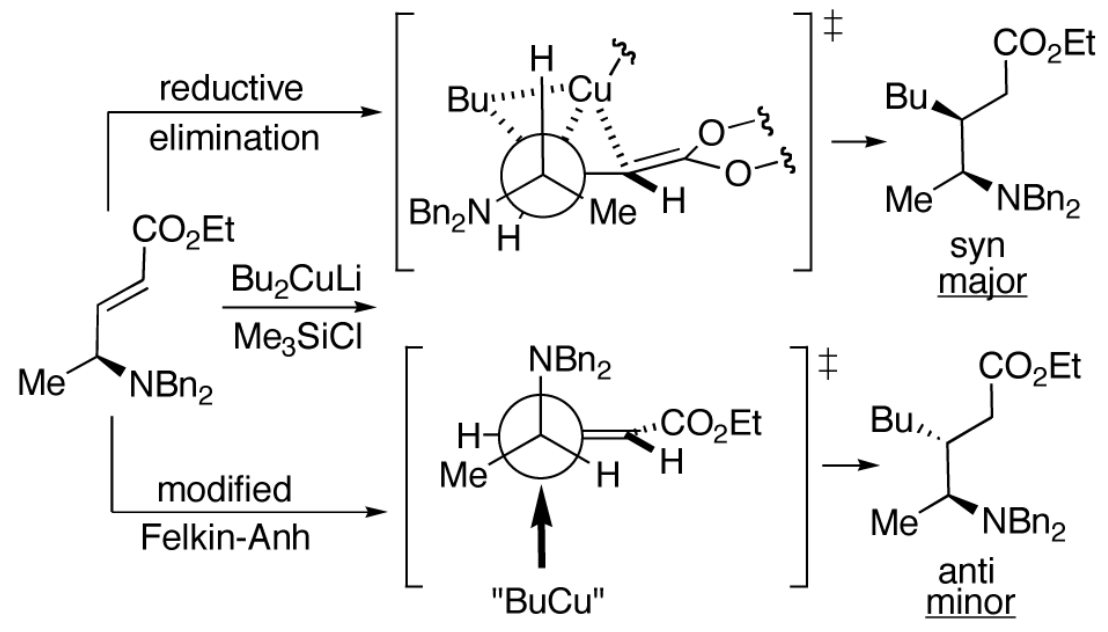

Figure 13.

Correct prediction of the stereochemical outcome of reactions of $\gamma$-amino- $\alpha, \beta$-enoates with the reductive elimination model and prediction of the opposite result with the modified FelkinAnh interpretation. $22 \mathrm{a}$ 


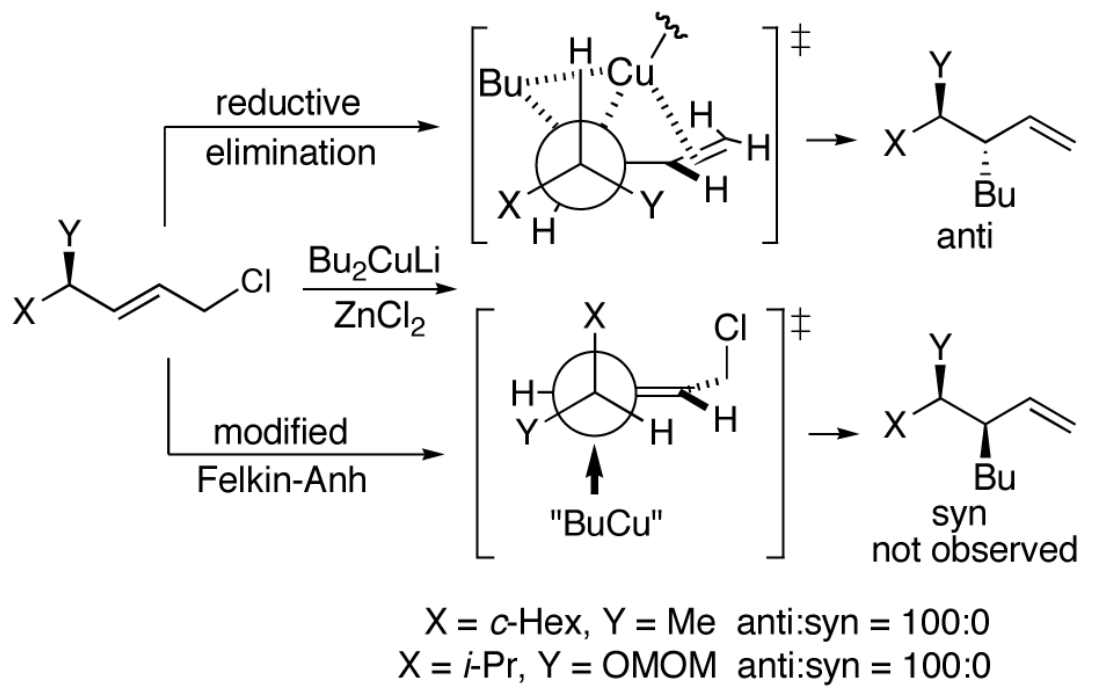

Figure 14.

Application of the reductive elimination model and the modified Felkin-Anh interpretation to $\mathrm{S}_{\mathrm{N}} 2^{\prime}$ processes indicating their mechanistic kinship to conjugate addition reactions. ${ }^{26}$ 
Table

Stereoselectivities of reactions of arylcuprates with trans and cis $\alpha, \beta$-enoates with a single $\gamma$-alkoxy stereocenter

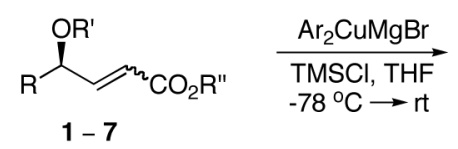

1-7

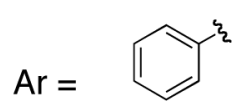<smiles>COc1ccc(I)cc1</smiles>

b<smiles>Fc1ccc(I)cc1</smiles>

c<smiles></smiles>

$12-18$<smiles>Cc1ccc2c(c1)OCO2</smiles>

d<smiles>COc1ccc(I)cc1OC</smiles>

e<smiles>COc1cc(I)cc2c1OCO2</smiles>

f

\begin{tabular}{|c|c|c|c|}
\hline enoate & adduct & $\%$ yield & anti:syn \\
\hline \multicolumn{4}{|c|}{ trans enoates } \\
\hline 1 & $12 a$ & 80 & $>50: 1$ \\
\hline 1 & $12 \mathrm{~b}$ & 78 & $>50: 1$ \\
\hline 1 & $12 \mathrm{c}$ & 79 & $>50: 1$ \\
\hline 1 & $12 d$ & 75 & $>50: 1$ \\
\hline 1 & $12 \mathrm{e}$ & 76 & $>50: 1$ \\
\hline 1 & $12 \mathrm{f}$ & 75 & $>50: 1$ \\
\hline 2 & 13a & 88 & $>50: 1$ \\
\hline 2 & 13d & 93 & $>50: 1$ \\
\hline 2 & $13 f$ & 82 & $>50: 1$ \\
\hline 3 & $14 a$ & 94 & $14.6: 1$ \\
\hline 3 & $14 d$ & 76 & $11.3: 1$ \\
\hline 3 & $14 f$ & 88 & 9.9:1 \\
\hline 4 & $15 a$ & 89 & $5.4: 1$ \\
\hline 4 & $15 d$ & 80 & $6.1: 1$ \\
\hline 4 & $15 f$ & 82 & $5.9: 1$ \\
\hline \multicolumn{4}{|c|}{ cis enoates } \\
\hline 5 & $16 a$ & 87 & $1.6: 1$ \\
\hline 5 & $16 d$ & 69 & $1: 1.3$ \\
\hline 5 & $16 f$ & 53 & $1: 1.3$ \\
\hline 6 & $17 \mathbf{a}$ & 72 & $2.8: 1$ \\
\hline 6 & 17d & 68 & $2.7: 1$ \\
\hline 6 & $17 f$ & 63 & $2.9: 1$ \\
\hline 7 & $18 \mathbf{a}$ & 65 & $3.4: 1$ \\
\hline 7 & $18 d$ & 56 & $1.9: 1$ \\
\hline 7 & $18 f$ & 54 & $2.2: 1$ \\
\hline
\end{tabular}

